\title{
Mythos
}

Rivista di Storia delle Religioni

13 | 2019

Varia

\section{Key-bearers of Greek Temples: The Temple Key as a Symbol of Priestly Authority}

Kleidouchoi nei santuari greci: la chiave del tempio come simbolo dell'autorità sacerdotale

\section{Aynur-Michèle-Sara Karatas}

\section{CpenEdition}

\section{Journals}

Electronic version

URL: http://journals.openedition.org/mythos/1219

ISSN: 2037-7746

\section{Publisher}

Salvatore Sciascia Editore

Electronic reference

Aynur-Michèle-Sara Karatas, « Key-bearers of Greek Temples: The Temple Key as a Symbol of Priestly Authority », Mythos [Online], 13 | 2019, Online since 06 November 2019, connection on 26 December 2019. URL : http://journals.openedition.org/mythos/1219

This text was automatically generated on 26 December 2019.

Mythos 


\title{
Key-bearers of Greek Temples: The Temple Key as a Symbol of Priestly Authority
}

Kleidouchoi nei santuari greci: la chiave del tempio come simbolo dell'autorità sacerdotale

Aynur-Michèle-Sara Karatas

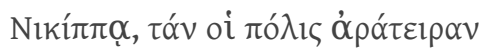

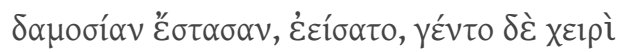

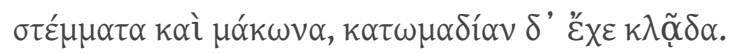

Nicippe, whom the city had appointed as her public priestess, and in her hand, she grasped her fillets and her poppy, and from her shoulder hung her key. Callimachus, Hymn to Demeter 42-44; translation MAIR, MAIR 1921.
\end{abstract}

\section{Introduction ${ }^{1}$}

1 The Greek poet Callimachus says that the city ${ }^{2}$ appointed Nicippe as public priestess of Demeter who held a wreath and a poppy in her hand and a key on her shoulder (Hymn to Demeter 42-44). The key and the wreath as signifiers of priestly status, and the poppy as an attribute of Demeter identify Nicippe as a priestess of Demeter. The temple key signifies the priestly authority and functions as an attribute of power in the hand of its holder. Callimachus uses the term $k \lambda \tilde{\alpha} \delta \alpha$ (klada), which is the Doric accusative form for

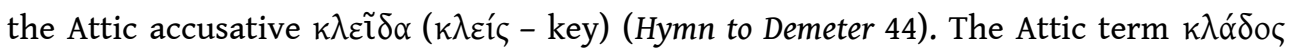
means branch. The key may be a metal bar bent twice at right angles in the shape of a branch hanging from the shoulder of Nicippe. It can also be another type of key. Homer tells us that Penelope used a metal bar to unlock the door (Od. 21.46-50). ${ }^{3}$ Homer's 
account provides evidence for metal bars used as keys in the 8th-7th centuries BCE. ${ }^{4}$ Modern scholars denote such bars as 'Homeric key' or 'temple key'. I will use the term ‘temple key' for this type of keys (Fig. 1).

Fig. 1. The bronze temple key from the sanctuary of Artemis at Lousoi

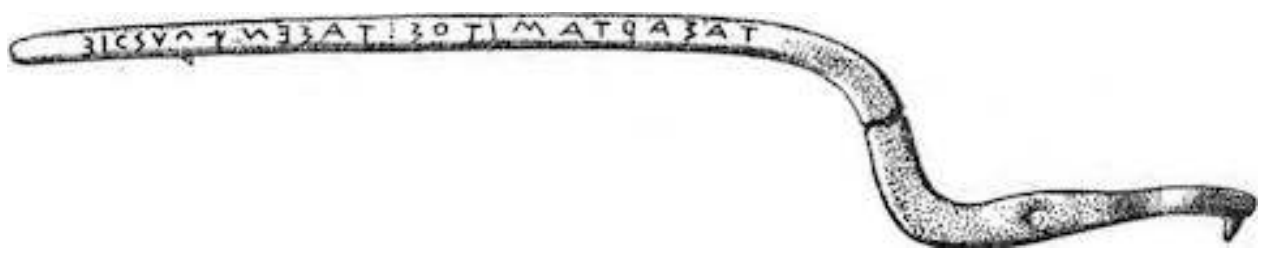

Diels 1914, 40, fig. 7

2 An inscribed bronze bar ( $40.5 \mathrm{~cm}$ in length) with such a shape and dating to the 5th century BCE was found at the sanctuary of Artemis in Lousoi (Museum of Fine Arts Boston Inv. 01.7515). The inscription on this bar suggests that it was dedicated as a votive by a cultic official, or it belonged to the sanctuary of Artemis at Lousoi (Fig. 1):

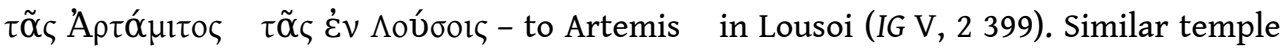
keys were also unearthed at various Greek sanctuaries. ${ }^{5}$ In general, temple keys found at other sanctuaries have a simple shape, are made of iron or bronze, and do not bear an inscription (Fig. 6). The temple keys were dedicated as votives or used as keys for buildings situated in the temene. With their simple mechanism, temple keys did not provide enough security for temples and treasury houses, which housed cult statues, valuable votives, and money. ${ }^{6}$ Even if the keys and lockers of most sanctuaries are not preserved, we can assume that the temples and other buildings, which housed costly votives and treasuries, were locked with the so-called Laconian keys (Fig. 2), which had sophisticated mechanism and offered more security. ${ }^{7}$ In Aristoph. Thesm. 421-428, women complain that they cannot open anymore the storerooms, since their husbands lock them with the Laconian keys. 
Fig. 2. A Laconian key

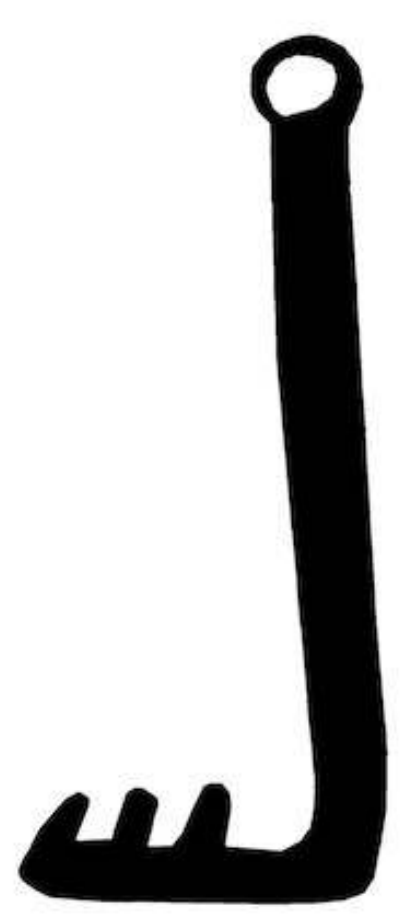

3 In Greek sanctuaries, the collective performances of rituals took place around an outdoor altar. As temples housed the images of deities, the temple door allowed the passage from one realm to another, from the profane space to the sacred. The door to the naos with the cult statue meant metaphorically the access to the presence of the god. A krater dating to the 4th century BCE from Taranto depicts the statue of Apollo in a temple, seen through the open doors.

4 Temples were, therefore, not always accessible for all worshippers. In some cases, only cultic officials were permitted entry. Some temples were open every day, and some only on certain days of the year. ${ }^{8}$ Locking and unlocking the temple door was the responsibility of either one or several cultic officials with the key signifying restricted access and custodianship. The key itself was entrusted to officials in their role as custodians of the temples. Valuable votives and money deposited in temples increased the responsibility of key-holders. For this reason, the temple key could only be entrusted to somebody of high social and cultic status. Most of the inscriptions about key-holders emphasize the noble background of key-holders. Therefore, we do not have evidence that the key-holders of most Greek sanctuaries were of noble background.

5 The key-holders of temples have a long tradition going back to the Mycenaean period. The Linear B tablets from Pylos dating to the second half of the 2nd millennium BCE mention cultic officials who had the title ka-ra-wi-po-ro (key-bearer). Key-holders were mentioned again in epigraphic sources almost 1000 years later. One of the earliest epigraphic sources on key-holders is from Attica and dates to $350 \mathrm{BCE}$ (IG II ${ }^{2} 4573$ ). Yet there are more than hundred inscriptions providing evidence for key-holders, which have not been analysed. This paper deals primarily with the evolution of cultic keyholders who are traceable through epigraphic sources from the Hellenistic period to late antiquity. The inscriptions were either dedicated by key-holders (hiereus 
inscriptions), or by the boule and the demos (honorary inscriptions). Only selected inscriptions dating from the 1st century BCE to 4th century CE will be subject of the analysis. From a multitude of pieces of epigraphic sources, I will explore the process of appointment of cultic officials as key-holders, their social and cultic status, gender, and cultic duties. Another question is whether there is a continuity of perpetuating the conception of key-holders of Greek temples.

6 So far, there are only very few studies on key-holders, which were mainly focused on the analysis of the iconographic material. Mantis made the first accurate analysis of the iconographic material on key-holders. ${ }^{9}$ One part of the iconographic material was also analysed by Dillon, Connelly, Kaltsas, and Shapiro. ${ }^{10} \mathrm{~A}$ significant number of vases and grave stelai dating to the Classical and Hellenistic periods depict temple keys or women holding a temple key. Most of the vases show mythical figures as key-holders, whereas the grave stelai honour women who served presumably as priestesses. I will only give an overview of the iconographic material on key-holders.

7 Some deities and mythical figures were also called key-holders or gatekeepers of different aspects of human and divine spaces. Homer portrays the Horai, goddesses of the seasons, as gatekeepers of the gates of heaven who opened or closed the thick cloud (Il. 8.393-396).$^{11}$ The Horai are, therefore, not called 'key-holders' of the gates of heaven. In Ov. Met. 2.115-118, it is Aurora, ${ }^{12}$ who opens the doors of heaven. Bremmer states that being a doorkeeper was not highly regarded, and it is surprising that the Horai, represented as young girls were doorkeepers, as it was considered to be inappropriate for young women to open the door for strangers. ${ }^{13}$ Bremmer considers various tasks, such as those of doorkeepers, as a "kind of initiatory status reversal" for divine girls before becoming a lady..$^{14}$ The key-holders of Hecate at Lagina were young girls. However, the Mycenaean key-bearers were presumably adult cultic officials, as they were entrusted with tasks, which could only be done by adults. The task of key-holder was not per se reserved to divine and mortal children. As we will see, deities and cultic officials denoted as key-holders were mostly adults.

8 The Orphic Hymns ${ }^{15}$ and the Papyri Graecae Magicae ${ }^{16}$ composed during the Hellenistic, Roman, and Imperial periods denote some deities linked to the afterlife as key-holders of the gates to Hades. The conception of key-holders of temples was projected on the most significant and powerful boundary that exist in the life and consciousness of living beings: the boundary connecting the world of the living to that of the dead. In the Greek world, it is especially Hecate, who was depicted with a key in the hand and was called key-holder of the gates to Hades and of the entire cosmos (Orphic Hymn to Hecate 7). The features of Hecate as divine key-holder will be partially analysed in this paper.

9 The Roman god Janus was a key-holder of heaven par excellence, symbolising beginning and transition (Ov. Fast. 1.99, 139, 228), ${ }^{17}$ and was depicted in Roman art with a key in the hand. The Latin word janua means door. Ovid portrays Janus as the guardian of the vast universe who regulates the goings and comings at heaven's gate (Fast. 1.117-226). There are similarities between Janus and Hecate in their role as divine key-holders.

Nonnus portrays the Greek lion-headed god Aion, who was associated with time and mysteries, as the holder of the keys of cosmos (Dion. 7.22). The Iranian Mithraic Kronos and Zurvan were also considered to hold the keys of heaven..$^{18}$ The Babylonian sun god Šamaš and the Phoenician god Rešef opened the gates of heaven. ${ }^{19}$ Kraus has suggested 
that Apollo was also a gatekeeper..$^{20}$ As a deity linked to light, Apollo was presumably a gatekeeper of the gates of heaven.

11 Some festivals celebrated in the Graeco-Roman world involved keys. Hecate had a festival of the key celebrated at Lagina. The highlight of the festival was the procession of the key. Numerous inscriptions dating mainly to the Imperial period commemorate the kleidophoroi (key-bearers) of Hecate at Lagina who carried the key in the procession of the key. ${ }^{21}$ The analysis of selected inscriptions from Lagina will explore the social and cultic status of key-bearers of Hecate. Hesychius mentions a festival called Epikleidia ( $E \pi / k \lambda \varepsilon i \delta_{1 \alpha}$ ) that was celebrated in honour of Demeter at Athens (s.v. $\dot{\varepsilon} \pi \imath k \lambda \varepsilon i \delta 1 \alpha) .{ }^{22}$ The name of the festival 'Epikleidia' suggests that the festival involved keys, but details are not known. A festival called Portunalia, ${ }^{23}$ which also involved keys, was celebrated at Rome in honour of the Roman god Portunus, whose name is derived from 'port', ${ }^{24}$ and who was associated with gates and keys. ${ }^{25}$ On the Portunalia, keys were burnt in the hearth as offering to Portunus (Ov. Fast. 6.547). ${ }^{26}$

\section{Mycenaean, Greek, and Latin terms denoting 'key- holder' and women as key-holders}

12 As mistresses of the household, women held the keys of their houses. According to

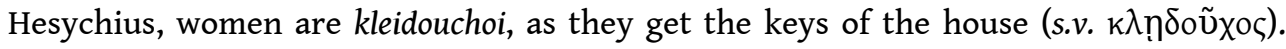
This means that the bride received the key from her future husband after the wedding when she entered the house of her groom. ${ }^{27}$ In the event of a divorce, the woman had to give back the keys. ${ }^{28}$ Festus mentions that it was a custom to give women a key as a symbol for an easy delivery. ${ }^{29}$ Women were not only key-holders of their households, but also as priestesses of temples.

13 The earliest epigraphic evidence for a term that denotes 'key-bearer' is from the Mycenaean period. Eleven Linear B inscriptions from Pylos use the term ka-ra-wi-po-ro to denote 'key-bearer' ${ }^{30}$ In ancient Greek, ka-ra-wi corresponds to $k \lambda$ ní $/ \kappa \lambda \varepsilon i ́ \varsigma$ (kleis) meaning key and -po-ro to - pópos. (phoros) meaning 'bearing'. The noun ka-ra-wi-poro $=$ klawiphoros $^{31}$ with the ending -os may refer to men as well as to women, ${ }^{32}$ suggesting that the key-bearers mentioned in Linear B tablets from Pylos were male or female cultic officials in charge of the key. The female name Karpathia (ka-pa-ti-ja) mentioned in PY Ep 704 indicates that the ka-ra-wi-po-ro was a woman. Apart from PY Ep 704, the other linear B tablets mentioned in this paper do not mention the gender of the ka-ra-wi-po-ro.

14 The explicit emphasis of the title ka-ra-wi-po-ro indicates that this office attained a particular significance in the Mycenaean society. The most significant cultic offices at

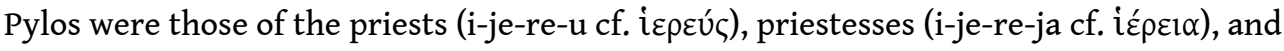
key-bearers (ka-ra-wi-po-ro). ${ }^{33}$ PY Ep 704 lists Karpathia alongside priestesses (see also $P Y E b$ 338A), meaning that she was also a priestess. Nakassis has suggested that Karpathia is identical with a woman mentioned in PY Un 443 who gave 200 litres of grain to the palatial authority (]do-ke). ${ }^{34}$ PY Fn 187 records that Karpathia distributed grain in cultic context. ${ }^{35}$ Shelmerdine states that Karpathia was one of two women mentioned in Linear B inscriptions from Pylos who were high ranking personalities of pa-ki-ja-ne and controlled a significant amount of land. ${ }^{36}$ The cultic official with the title ka-ra-wi-po-ro was linked to pa-ki-ja-ne that was an important sanctuary or 
district. ${ }^{37}$ Olsen concluded that the key-bearers at Pylos had the same standing as priestesses and controlled "land holdings, textiles, and foodstuffs". ${ }^{38}$ The different duties of the ka-ra-wi-po-ro included the responsibility for the keys of the temple and buildings, where treasuries, food, and textile were deposited. The Linear B inscriptions indicate that the ka-ra-wi-po-ro was a landholder ( $P Y E b 338)^{39}$ and had slaves ( $P Y A e$ 110). PY Jn 829 mentions that the ka-ra-wi-po-ro had to contribute a certain amount of bronze as temple tax to the palace along with other officials, including the mayors, vice-mayors, and overseers of figs, suggesting that the ka-ra-wi-po-ro held a high position in the Pylian society, requiring him/her to contribute along with leading members of the Pylian society.

Various ancient Greek dialects have different terms to denote key-holders: $k \lambda \varepsilon 1 \delta \circ \tilde{x} \chi \circ /$

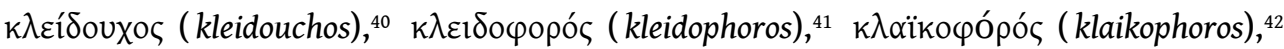

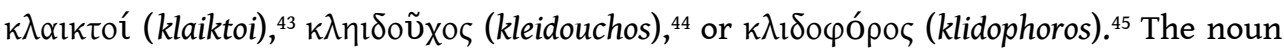

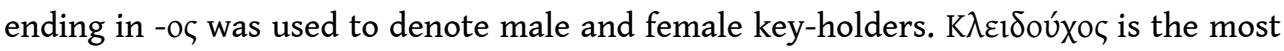

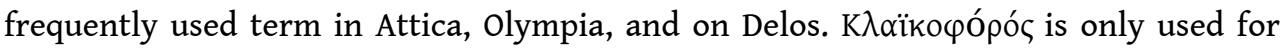
heroes in inscriptions from the Peloponnese. ${ }^{46} T$ he inscriptions from Lagina, Panamara,

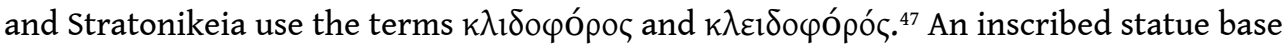
dedicated to Artemis Limnatis (3rd-2nd centuries BCE) and found at Apollonia in Illyria ${ }^{48}$ uses the term $\kappa \lambda \alpha \kappa \circ \varphi$ ор $\sigma \alpha \alpha \sigma \alpha$ to denote 'key-bearer' (I.Apollonia 16). This term is similar to that used for heroes. A sanctuary of Artemis Limnatis is attested by archaeological evidence for Mount Taygetos located in the Peloponnese. ${ }^{49}$ People from the Peloponnese may have established the cult of Artemis Limnatis at Apollonia. This can be the reason why the key-holder of Artemis Limnatis was also called klaikophoros.

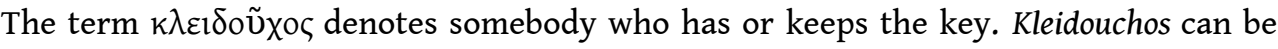
translated as 'key-holder' or 'keeper of the key'. The most common term used by different scholars for kleidouchos is 'key-bearer' in English, 'Schlüsselträger' in German,

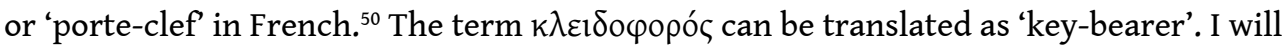

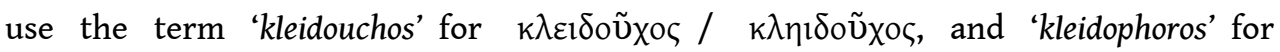

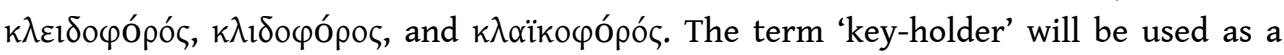
general term for kleidouchos and kleidophoros. It is not always obvious whether the two terms describe different tasks or are related to regional preferences of terms, as the inscriptions do not describe in detail the tasks of kleidouchos and kleidophoros. The ending -phoros may suggest that the office-holder carried a key. The cultic officials of Hecate at Lagina called kleidophoroi carried a key at the festivals of Hecate. Heroes called 'klaikophoroi' in inscriptions functioned presumably as protectors of the doors/ gates. The literary sources do not mention that the task of heroes as key-holders implied a procession with the key. The kleidophoros had presumably the same task as the kleidouchos: locking and unlocking the temple door, the performance of rituals, and escorting the temple key in processions. Only a few inscriptions mention a procession with a key, but they do not mention cultic officials who were called kleidouchoi or kleidophoroi.

17 The Latin term for 'key-holder' is claviger (Ov. Fast. 1.228) that is composed by two words: clavis (key) and gerere (to bear). Pliny uses the term cliduchus for key-holder ( $\mathrm{NH}$ 34.19). Some of the late antique Christian authors use the term clāviculārius to denote 'key-holder', which also means 'jailer'. ${ }^{51}$ Clāviculārius is derived from clāvicula that means 'small key' and 'tendril'. Hyginus Gromaticus uses the term clāvicula for a bar of door ${ }^{52}$ that recalls the metal bar used for bolt lockers. 
the temple keepers of Roman sanctuaries were called aeditui who were in charge of the temple key. In contrast to the Greek key-holders, the aeditui were slaves or free born people with low social status..$^{53}$ Ménard has pointed out that some aeditui were wealthy and able to afford to dedicate costly altars and sarcophagi. ${ }^{54}$ As money, valuable votives, and important documents were also deposited in Roman temples, the aeditui functioned as guardians of the temples. Such a function is not attested by epigraphic sources for Greek key-holders. The aeditui guarded the temples on daily basis and were in charge of locking and unlocking the temple door in the morning and in the evening. ${ }^{55}$ For the performance of rituals by cultic officials and worshippers, the temple was opened in the morning and closed in the evening, or later at night. Worshippers had to respect certain rules at each temple and to perform the rituals as ordered. The aeditui made sure that all rules were respected by worshippers and rituals were performed as prescribed at each temple. ${ }^{56}$ The Greek inscriptions do not provide evidence to indicate that the Greek key-holders were monitoring the worshippers and made sure that the rules of the sanctuaries were respected.

\section{Iconographic material on temple key and key-holders}

A clay figurine dating to the 6th century BCE from the sanctuary of Artemis on Corcyra is the earliest representation of a key-holder in Greek art that depicts a woman holding a temple key in her left hand and a bird in her right hand (Fig. 3). ${ }^{57}$

Fig. 3. Clay figurine (6th century BCE) from the sanctuary of Artemis on Corcyra

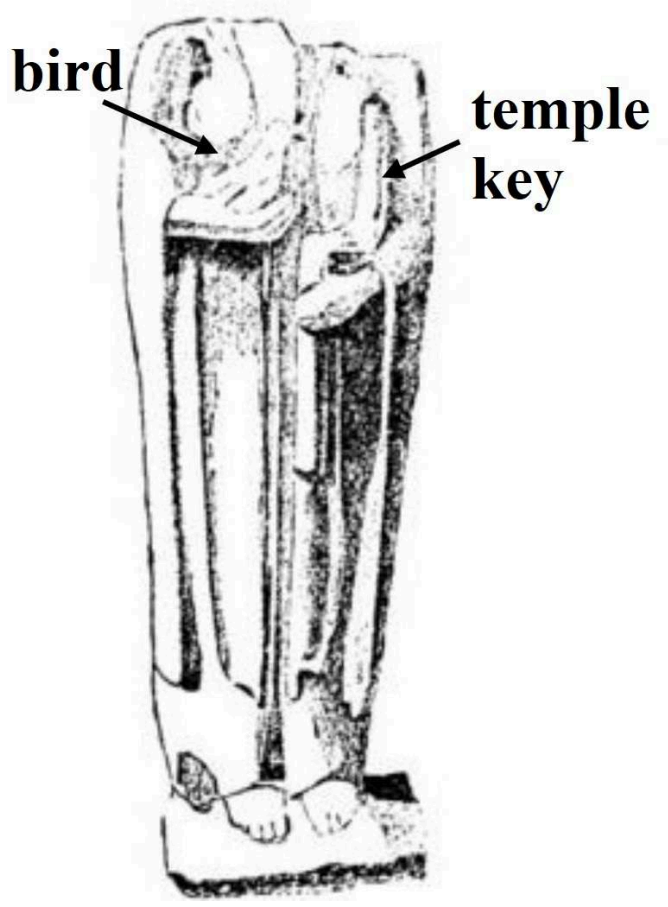

Lechat 1891, 32, fig. 4

The sculptural representation of key-holders is also attested for Cyprus. A life-size limestone statue from Idalion (Cyprus) dating to the 3rd century BCE represents a 
veiled woman holding a temple key under her left arm (Museum Louvre Inv. N 3278). Another limestone statue from Cyprus depicts a veiled woman with a similar gesture (Archaeological Museum of Larnaka Inv. 663). Presumably, the clay figurine from Corcyra and the two statues from Cyprus represent priestesses, and the temple key served as an iconographic insignia of female priests. Pliny mentions that each of two Greek sculptors, Phidias (480-430 BCE) and Euphranor (364 BCE), made a statue of a female kleidouchos ( $\mathrm{NH} 34.19 .54,77)$. The statues of both sculptors are, however, not preserved. A statue (3rd-2nd centuries BCE) dedicated by a key-bearer of Artemis Limnatis depicts a young woman whose arms and head are broken. She might have been depicted with a key in the hand. We learn from the inscription engraved on the statue base that Myrto, the daughter of Kironos, was the key-bearer of Artemis Limnatis (I.Apollonia 16).

21 Numerous Greek vase paintings and grave stelai depict female key-holders. Despite the high number of Greek inscriptions commemorating male key-holders, men were seldom depicted with a temple key in Greek art (Chart 2). Male priests were usually not depicted with a temple key, as the temple key was not the insignia of male priestly status. ${ }^{58} \mathrm{~A}$ clay figurine from Locri Epizefiri shows a man holding a temple key. ${ }^{59}$ The painted pediment of the Tomb of the Palmettes at Lefkadia (Macedonia) dating to the 3rd century BCE shows another iconography of a male key-holder who holds a temple key decorated with woollen ribbons. ${ }^{60}$ Woollen ribbons hanging from the key highlight its cultic context, as they appear in a sacral context. ${ }^{61}$ The other male key-holder depicted in Greek art is the mythical figure Chryses, the priest of Apollo (Dictys Cretensis 2.14), who appears with a temple key on his shoulder on an Apulian redfigured volute crater (Museum Louvre K1). This is the only crater that depicts a male key-holder who is in the centre of the scene.

At least twenty-two vases dating to the 4th century BCE depict mythical figures (Iphigenia, Pythia, Theano, and Io) and mortal women as key-holders (Table 1).

Table 1: Greek vases depicting mythical and mortal figures as key-holders

\begin{tabular}{|l|l|l|l|}
\hline key-holder & vase type and painter & period & references, museum \\
\hline Iphigenia & $\begin{array}{l}\text { red-figured calyx crater } \\
\text { by the Iphigenia Painter } \\
\text { from South Italy }\end{array}$ & $5^{\text {th }}$ C. BCE & $\begin{array}{l}\text { Euripides, Iphigenia in Tauris 1153-1190; } \\
\text { LIMC } 2 \text { V.1 1990: 714, no. 19; MANTIS 1990: 19, } \\
\text { a; Ferrara, Archaeological Museum T1145 }\end{array}$ \\
\hline Iphigenia & Attic crater & $380 \mathrm{BCE}$ & $\begin{array}{l}\text { Euripides, Iphigenia in Tauris 578-642; Museo } \\
\text { Nazionale di Spina T.1145 }\end{array}$ \\
\hline Iphigenia & Apulian crater & $365-360$ BCE & $\begin{array}{l}\text { LIMC V.1 1990, 713, no 14; Musei Civici di } \\
\text { Pavia }\end{array}$ \\
\hline Iphigenia & Apulian crater & $350 \mathrm{BCE}$ & $\begin{array}{l}\text { LIMC V.1 1990, 714, no. 18; MANTIS 1990: 19, b; } \\
3223\end{array}$ \\
\hline Iphigenia & Apulian amphora & $350 \mathrm{BCE}$ & $\begin{array}{l}\text { LIMC V.1 1990, 715, no. 21; New York, } \\
\text { Atlantis Antiquities }\end{array}$ \\
\hline
\end{tabular}




\begin{tabular}{|c|c|c|c|}
\hline Iphigenia & Apulian crater & $345-340 \mathrm{BCE}$ & $\begin{array}{l}\text { LIMC V.1 1990, 715, no. 22; Moscow, Pushkin } \\
\text { Museum of Fine Arts } 504\end{array}$ \\
\hline Iphigenia & Apulian amphora & $\begin{array}{l}\text { Mid-4th c. } \\
\text { BCE }\end{array}$ & $\begin{array}{l}\text { The amphora is lost; LCIM V.1 1990: 715, no. } \\
\text { 20; MANTIS 1990, 20, a }\end{array}$ \\
\hline Iphigenia & $\begin{array}{ll}\text { Amphora } & \text { from } \\
\text { Campania } & \end{array}$ & $\begin{array}{l}\text { 3rd quarter } \\
\text { of the } 4^{\text {th }} \mathrm{c} \text {. } \\
\text { BCE }\end{array}$ & $\begin{array}{l}\text { LIMC V.1 1990, 715, no. 25; MANTIS 1990: 20, b; } \\
\text { Sydney, Nicholson Museum } 51.17\end{array}$ \\
\hline Iphigenia & Apulian amphora & $330-320 \mathrm{BCE}$ & $\begin{array}{l}\text { LIMC V.1 1990, 715, no. 23; St. Petersburg, } \\
\text { The State Hermitage Museum B 1715A }\end{array}$ \\
\hline Iphigenia & Darius Painter & & LIMC V.1 1990, 715, no 24 \\
\hline Theano (?) & $\begin{array}{l}\text { red-figure crater from } \\
\text { Paestum by Asteas }\end{array}$ & $350-340 \mathrm{BCE}$ & $\begin{array}{l}\text { LIMC VII.1 1994, 912, no. 9; Rome, Museo } \\
\text { Nazionale Etrusco di Villa Giulia } 50.279\end{array}$ \\
\hline Theano (?) & $\begin{array}{l}\text { hydria from Nola } \\
\text { (Campania) }\end{array}$ & $4^{\text {th }} \mathrm{C} \cdot \mathrm{BCE}$ & London, British Museum 1824.5.1.35 \\
\hline Theano (?) & crater from South Italy & & $\begin{array}{l}\text { St Petersburg, The State Hermitage Museum } \\
\text { St. } 298\end{array}$ \\
\hline Theano (?) & $\begin{array}{l}\text { amphora from Paestum, } \\
\text { Boston Oresteia Painter }\end{array}$ & & $\begin{array}{l}\text { Euripides, Iphigenia in Tauris } 244-245,622 \text {; } \\
\text { MANTIS 1990, 26, a; LIMC VII.1 1994, 912, no. 8; } \\
\text { Vienna, Kunsthistorisches Museum } 724\end{array}$ \\
\hline Theano (?) & Apulian crater & & $\begin{array}{l}\text { Museo Nazionale Archeologico di Taranto } \\
52665\end{array}$ \\
\hline Pythia (?) & $\begin{array}{l}\text { Apulian crater by Black } \\
\text { Fury painter }\end{array}$ & $4^{\text {th }}$ C. BCE & $\begin{array}{l}\text { Aesch. Eum. 34-59, 63; Naples, Museo } \\
\text { Archeologico Nazionale } 82270\end{array}$ \\
\hline Pythia (?) & crater from South Italy & $370-360 \mathrm{BCE}$ & $\begin{array}{l}\text { St Petersburg, The State Hermitage Museum } \\
\text { St. } 1734\end{array}$ \\
\hline woman & Attic hydria & & Boston Museum of Fine Arts 417 \\
\hline $\begin{array}{l}\text { elderly } \\
\text { priestess }\end{array}$ & Apulian volute crater & $350 \mathrm{BCE}$ & London, British Museum 1931,0511.1 \\
\hline Chryses & $\begin{array}{l}\text { Apulian crater by } \\
\text { Painter of Athens } 1714\end{array}$ & $360-350 \mathrm{BCE}$ & $\begin{array}{l}\text { Hom. Il. 1, 383-396; LIMC III.1 1986, 283; } \\
\text { Paris, Museum Louvre CA 227; }\end{array}$ \\
\hline $\begin{array}{l}\text { mortal } \\
\text { woman (?) }\end{array}$ & Apulian skyphos & $360-340 \mathrm{BCE}$ & London, British Museum. 1867,0508.1174 \\
\hline $\begin{array}{l}\text { mortal } \\
\text { woman (?) }\end{array}$ & Apulian crater & & Vienna, Kunsthistorisches Museum 1115 \\
\hline
\end{tabular}


The mythical figures are depicted in vase paintings as key-holders of various deities. Some of these mythical key-holders are linked to Homer's epic and some to the myth of Orestes. Theano was a priestess of Athena who opened the door of the temple (Hom. Il. 6.297-301). Iphigenia was the key-holder and gate-keeper of the temple of Artemis at Brauron (Eur. IT 131, 1152, 1461-1465). Io was the key-holder of Hera at Argos (Aesch. Supp. 291). Hecuba, who was the queen of Troy, says in Eur. Tro. 256 that her daughter Cassandra, who was the key-holder of Apollo, should cast from her the sacred keys. Pythia, the priestess of Apollo at Delphi, is not described in literary sources as a keyholder but represented in a vase painting as kleidouchos. The Apulian crater by the Black Fury Painter depicts a scene from the Oresteia (Fig. 4). The omphalos in the temple indicates that the scene takes place at Delphi, and the priestess who flees and drops a temple key is the Pythia.

Fig. 4. The crater by the Black Fury Painter depicts the Pythia (?) as key-holder

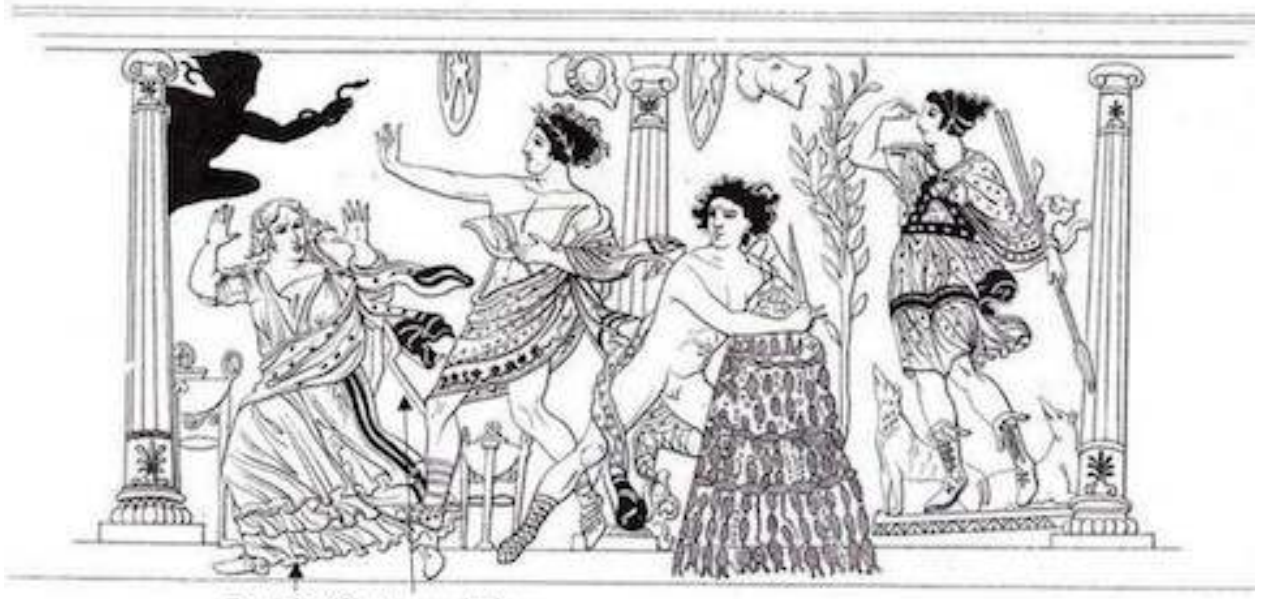

Pythia (?) temple key

Bötticher 1859, fig. 1; photo edited by author

Apart from a red-figure crater by the Iphigenia Painter (5th century BCE), the other vase paintings date to the second half of the 4 th century BCE. The dedication of grave stelai, which depict key-holders or a temple key, also begins in the second half of the 4th century BCE. Apart from one vase from Attica (Museo Nazionale di Spina T.1145), all vase paintings are from South Italy and were produced by the Apulian workshops. The representation of key-holders is mostly absent in Attic vase painting. Grave stelai honouring cultic officials with a temple key are absent in Magna Graecia. Greeks in Attica and Magna Graecia had different preferences concerning vase painting and the representation of priestesses on grave stelai. Connelly has suggested that the scenes from the theatre were popular in South Italian vase painting, and the iconography of mythical key-holders was derived from the dramatic scenes. ${ }^{63}$ Taplin and Nervegna show that the plays of Aeschylus and Euripides, who described some mythical figures as key-holders, were very popular in South Italy in the 4th century BCE and influenced vase painting. ${ }^{64}$ Presumably, Aeschylus and Euripides used the temple key as a status marker for priestesses, and this was also depicted in vase painting. 
Twelve grave stelai dating to the 4th-1st centuries BCE depict a temple key or women holding a temple key (Table 2). The grave reliefs depict the deceased holding a temple key in the hand or on the shoulder.

Fig. 5. Grave stele of Polystrate from Kerameikos dating to the early 4th century BCE. Polystrate holds the temple key in her right hand

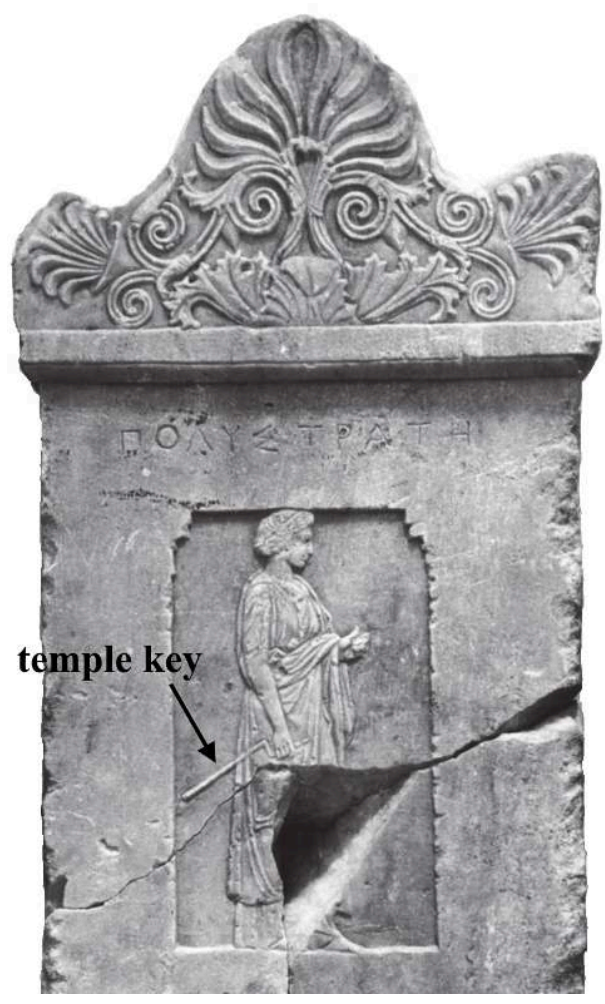

KALTSAS, SHAPIRO 2008, 206; Kerameikos Museum, I 430/P1142; courtesy of A. Shapiro and DAl; photo edited by author

Kosmopoulou states that the self-representation of women on Attic grave stelai after the Peloponnesian War was not only focused on oikos, but also on profession. ${ }^{65}$ This is not a phenomenon restricted to women. It is in the Hellenistic and in the following periods that women as well as men emphasized their cultic offices in inscriptions. Most grave stelai listed in the Table 2 are from Attica. Only five grave stelai, which depict a temple key, were dedicated outside Attica. Bielman Sánchez believes that the temple key served as a signifier of priestly status not only in Attica but in the whole of the Greek world ${ }^{66}$ Even if the temple key was an insignia of female priests, priestesses in different regions used other symbols to emphasize their priestly status. Not only in other regions, most grave stelai of women from Attica who were identified as priestesses do not use the temple key as an insignia of cultic offices. Attributes, cult objects linked to certain deities, and inscriptions identify the deceased as a priestess of a deity. Some grave stelai depict the priestesses of Isis wearing garments associated with the cult of Isis. 14 grave stelai (2nd century BCE) found at Smyrna were dedicated by the demos and depict women holding a torch ${ }^{67}$ As torch was an attribute of Demeter, several scholars assume that these stelai were dedicated by the demos to the priestesses of Demeter. ${ }^{68}$ These stelai may also have been dedicated to priestesses of other goddesses (e.g. Artemis or Hecate) who were also represented with torches. These two 
examples illustrate how attributes of deities and objects linked to various cults were used as an iconographic marker for priestly status.

The grave stele of Isias from Smyrna (2nd-1st centuries BCE) is the only stele that depicts a woman holding a Laconian key (British Museum Inv. 1772,0703.1). Isias was presumably a priestess of the Egyptian deities, as her garment is typical for priestesses of Isis. ${ }^{69}$ Numerous inscriptions from Delos honouring key-holders of the Egyptian deities were also dedicated in the 2nd-1st centuries BCE. The key-holders of the Egyptian deities mentioned in the inscriptions from Delos were men. As far as I am aware, statues or reliefs of male priests holding a temple key are not attested for any cult.

Most grave stelai bear an inscription that only mention the name of the deceased woman, the name of her father and husband (Table 2). Only two inscriptions mention the priestly office of the deceased. IG VII 2676 records that Noumenides, who is depicted with a temple key, was a priestess of Demeter. IG II ${ }^{2} 6288$ refers to Chairestate, who was a priestess of the Mother of all children. The stele of Chairestate depicts a seated woman who holds a temple key in her hand. A girl who stands on the right-hand side holds a tympanon. The tympanon and the title 'Mother of all children' suggest that Chairestate was a priestess of Cybele, who was called 'Great Mother'. The temple key was used as a signifier of priestly status on the stelai of Chairestate and Noumenides.

Table 2: Grave stelai depicting temple key and key-holders

\begin{tabular}{|c|c|c|c|c|c|}
\hline inscription & city & region & period & $\begin{array}{l}\text { name of } \\
\text { the } \\
\text { deceased }\end{array}$ & description, museum \\
\hline- & Rhamnous & Attica & $\begin{array}{l}380-370 \\
\text { BCE }\end{array}$ & - & $\begin{array}{l}\text { A standing woman holds a temple } \\
\text { key in her left hand; Athens, } \\
\text { National Archaeological Museum } \\
\text { Inv. Г 2309; }\end{array}$ \\
\hline- & Athens & Attica & $4^{\text {th }}$ c. BCE & - & $\begin{array}{l}\text { The relief of a lekythos depicts a } \\
\text { seated man who gives his hand to } \\
\text { the woman standing next to him. } \\
\text { The woman holds a temple key with } \\
\text { her left hand on her left shoulder. } \\
\text { Two women are standing behind the } \\
\text { man; Athens, National } \\
\text { Archaeological Museum Inv. } 56167\end{array}$ \\
\hline- & Taras & $\begin{array}{l}\text { Magna } \\
\text { Graecia }\end{array}$ & & - & $\begin{array}{l}\text { A relief depict two seated women } \\
\text { and an woman standing and holding } \\
\text { a temple key on her left shoulder; } \\
\text { Princeton, The Art Museum Inv. } \\
\text { 1985-84 }\end{array}$ \\
\hline IG II $^{2} 13062$ & Eleusis & Attica & $370-360$ & Choirine & $\begin{array}{l}\text { A woman holds a temple key in her } \\
\text { right hand; London, British Museum } \\
\text { Inv. 2007,5001.1 }\end{array}$ \\
\hline
\end{tabular}




\begin{tabular}{|c|c|c|c|c|c|}
\hline$I G I^{2} 6288$ & Piraeus & Attica & $\begin{array}{l}360-350 \\
\text { BCE }\end{array}$ & Chairestate & $\begin{array}{l}\text { A seated woman holds a temple key } \\
\text { in her left hand, and a girl standing } \\
\text { on the right hand-side holds a } \\
\text { tympanon; Chairestate was a } \\
\text { priestess of the mother of all } \\
\text { children; Piraeus, Archaeological } \\
\text { Museum Inv. } 1031\end{array}$ \\
\hline SEG 22:199 & Kerameikos & Attica & $\begin{array}{l}\text { early } 4^{\text {th }} \\
\text { c. BCE }\end{array}$ & Polysrate & $\begin{array}{l}\text { A standing woman holds a temple } \\
\text { key in her right hand; Athens, } \\
\text { Kerameikos Museum Inv. 1430/ } \\
\text { P1142 }\end{array}$ \\
\hline IG VII 2021 & Thebes & Boeotia & $\begin{array}{l}250-200 \\
\mathrm{BCE}\end{array}$ & Theomnasta & $\begin{array}{l}\text { A funerary altar depicts a temple } \\
\text { key and an ivy wreath; }{ }^{70} \text { Thebes, } \\
\text { Archaeological Museum Inv. } 400\end{array}$ \\
\hline $\begin{array}{l}\text { Roesh, } \\
\text { IThesp } 756\end{array}$ & Thebes & Boeotia & $\begin{array}{l}250-200 \\
\text { BCE }\end{array}$ & Euphantis & $\begin{array}{l}\text { A funerary altar depicts a temple } \\
\text { key; Thebes, } \quad \text { Archaeological } \\
\text { Museum Inv. } 402\end{array}$ \\
\hline I.Smyrna 10 & Smyrna & Ionia & $\begin{array}{l}2^{\text {nd }}-1^{\text {st }} c . \\
B C E\end{array}$ & Isias & $\begin{array}{l}\text { A woman standing next to a tree } \\
\text { holds a Laconian key in her right } \\
\text { hand; London, British Museum Inv. } \\
1772,0703.1\end{array}$ \\
\hline IG $\mathrm{II}^{2} 6398$ & Athens & Attica & $\begin{array}{l}\text { second } \\
\text { half of } \\
\text { the } 2^{\text {nd }} c . \\
\text { BCE }\end{array}$ & Habryllis & $\begin{array}{l}\text { A column depicts a temple key; } \\
\text { Athens, National Archaeological } \\
\text { Museum Inv. Г } 1727\end{array}$ \\
\hline$I G \mathrm{II}^{2} 6232$ & Athens & Attica & $\begin{array}{l}\text { early } 1^{\text {st }} \mathrm{c} . \\
\text { BCE }\end{array}$ & Mneso & $\begin{array}{l}\text { A column depicts a temple key; } \\
\text { Athens, Epigraphic Museum Inv. } \\
11144\end{array}$ \\
\hline IG II $^{2} 7356$ & Athens & Attica & $1^{\text {st }} \mathrm{c} \cdot \mathrm{BCE}$ & Theophile & $\begin{array}{l}\text { A column depicts a temple key; } \\
\text { Athens, Epigraphic Museum Inv. } \\
11183\end{array}$ \\
\hline IG VII 2676 & Thebes & Boeotia & $\begin{array}{l}\text { Imperial } \\
\text { period }\end{array}$ & Noumenides & $\begin{array}{l}\text { Noumenides, a priestess of Demeter, } \\
\text { is depicted with a temple key }\end{array}$ \\
\hline
\end{tabular}

\section{Epigraphic sources on key-holders of Greek sanctuaries}

At least 110 inscriptions dating from the 4th century BCE to the 4th century CE mention male and female key-holders (Table 3; Chart 1). IG II $^{2} 4573$ from Athens dates to $350 \mathrm{BCE}$ and is the first inscription that honours a key-holder. Most inscriptions from Athens date from the 2nd to 1st centuries BCE. The epigraphic record on key-holders began in 
Olympia and Asia Minor approximately 100 years later (Table 3). Athens, where the epigraphic record on key-holders seems to have its beginning, has presumably influenced other cities. The inscriptions are mainly from Attica, Olympia, Delos, Lagina, and Panamara: At least 17 inscriptions are from Attica; ${ }^{71} 6$ from Olympia; $; 23$ from Delos; ${ }^{73} 41$ from Lagina, Panamara and Stratonikeia; ${ }^{74}$ and single inscriptions from Troizen (IG IV 768, line 2), Epidaurus (IG IV ${ }^{2}, 1297$, line 1), Argos (SEG 48:411), ${ }^{75}$ Messene (IG V,1 1447, line 11), Syros (IG XII,5 713(5)), Cos (Iscr. di Cos ED 102, lines 7-8; IG XII 4, 1, 71), ${ }^{76}$ Teos (CIG 3123, line 7), Klaros (JÖAI 8 (1905) 168,4/5.3, line 7), Side (IK Side I 17), Apollonia in Illyria (I.Apollonia 16, lines 3-4), and Rome (IGUR III 1245, line 14). ${ }^{77}$

The inscriptions commemorate the key-holders of various deities: Asclepius, ${ }^{78}$ Egyptian deities ${ }^{79}$ Hera, ${ }^{80}$ Zeus, ${ }^{81}$ Athena, ${ }^{82}$ Demeter,${ }^{83}$ Apollo, ${ }^{84}$ Artemis, ${ }^{85}$ Leto, ${ }^{86}$ Aphrodite, ${ }^{87}$ and Hecate ${ }^{88}$ The inscriptions from Athens honour the key-holders of Asclepius, Hygeia, Artemis, and the Egyptian deities. ${ }^{89}$ The inscriptions from Olympia date to 50-16 BCE and list the key-holders alongside other cultic officials of Zeus at Olympia. Only one inscription from Olympia dates to 5 CE (IvO 69). Single inscriptions about key-holders from different cities in the Peloponnese date from the 3rd to 2 nd centuries BCE. ${ }^{90} \mathrm{In}$ contrast to other cities, most inscriptions from the Peloponnese, apart from Olympia, honour heroes as key-holders. Inscriptions from Lagina, Panamara, and Stratonikeia date from the 1st centuries BCE to the 4th century CE and honour the key-holders of Hecate. The inscriptions from Delos date from the 2nd to 1st centuries BCE and commemorate the key-holders of the Egyptian deities, Zeus Kynthos, Athena Kynthia, Artemis, Apollo, Leto, Agathe Tyche, and Aphrodite. Key-holders of many cults are only attested for Delos. In other cities, only the key-holders of one or two cults were commemorated in epigraphic sources. It seems likely that not all cults in a city had an office of key-holder, or it did not have the same cultic status as those of a few cults recorded in inscriptions.

Table 3. Chronology of epigraphic and iconographic material concerning key-holders. For inscriptions from Attica, Olympia, Delos, Lagina, and Panamara, see fn. 41, 45, 71, and 73. For the iconographic material, see Table 1-2.

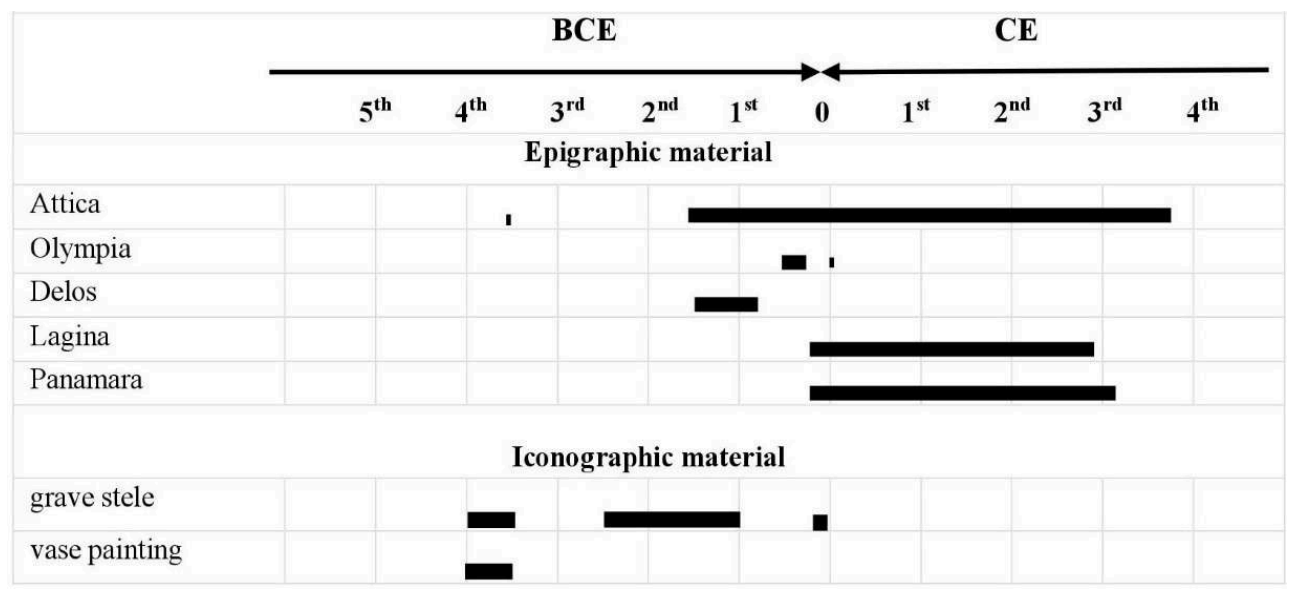




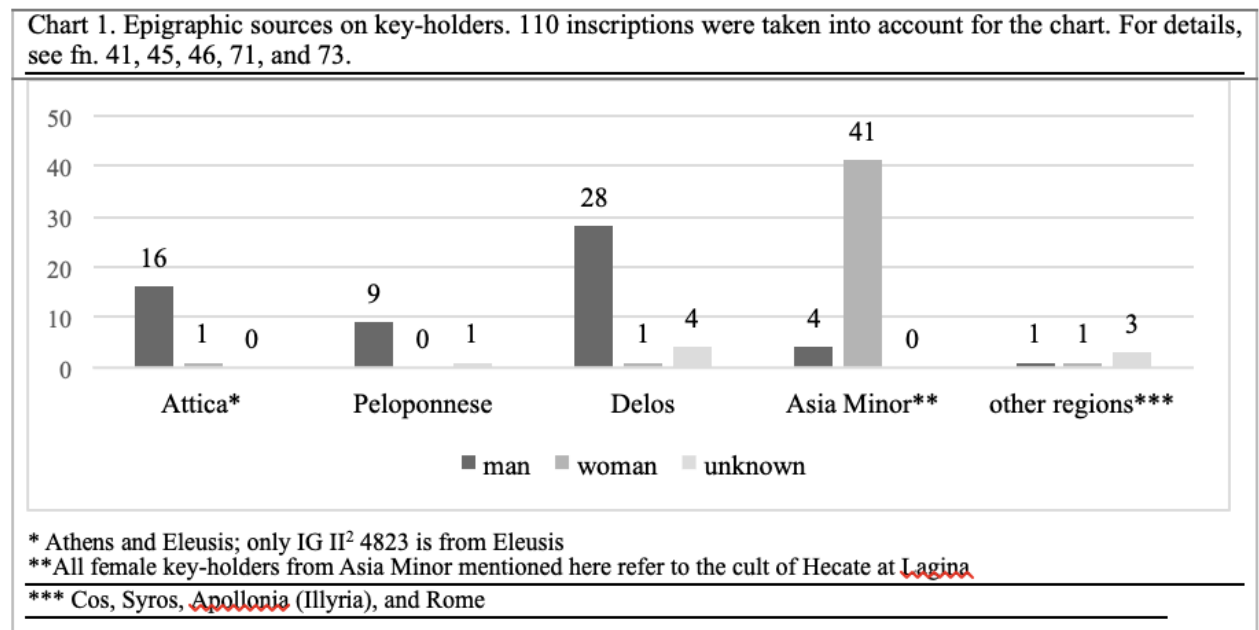

31 In contrast to key-holders depicted in vase painting and grave stelai, most key-holders mentioned in inscriptions are men (Chart 2). More than $53 \%$ of inscriptions refer to male and $44 \%$ to female key-holders (Chart 1). Almost all key-holders mentioned in inscriptions from mainland Greece and Delos were men, whereas those from Asia Minor were almost all women. The cult of the Egyptian deities at Athens and on Delos had male priests and male key-holders. The sanctuary of Asclepius at Athens also had male priests and male key-holders. The sanctuary of Hecate at Lagina had male and female priests. A married couple served as priest and priestess of Hecate at Lagina and appointed their own daughter or the daughter of another family to key-holder. The priest of Asclepius at Athens also appointed his son or the son of another family to keyholder.

Chart 2. The gender of key-holders depicted in vase painting, grave stelai, and mentioned in epigraphic sources. For details, see Table 1-2 and Chart 1.

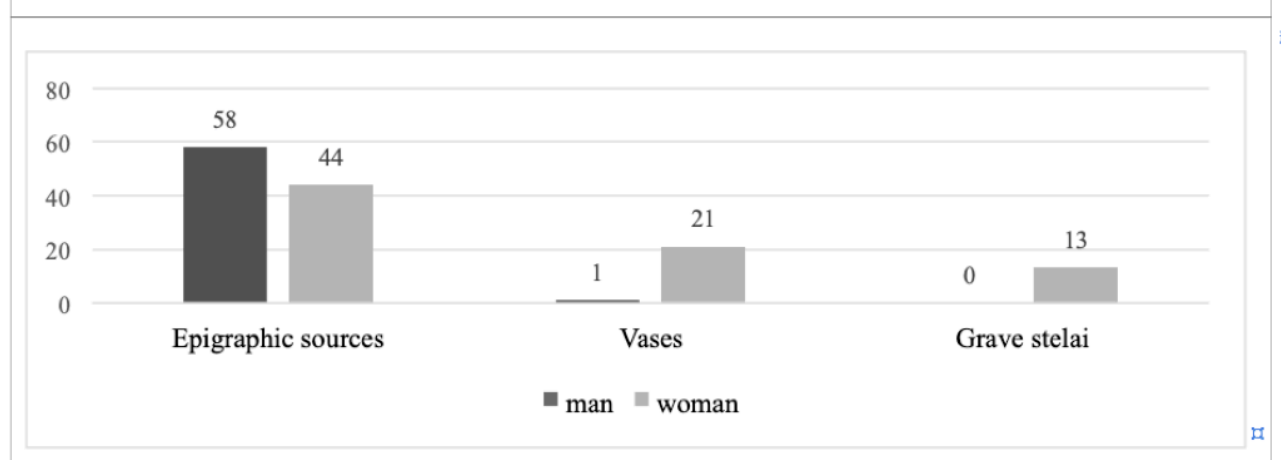

Almost all inscriptions indicate that the priests and the key-holders were different cultic officials. Only in few cases, the priest was also the key-holder. IG II $^{2} 4573$ from Athens reveals that a woman was an attendant and kleidouchos of Artemis Agrotera (of the fields). The priests of many small sanctuaries were presumably also in charge of the temple key. The tasks at major sanctuaries were divided between the chief priests and other cultic officials. Probably for this reason, most epigraphic sources on key-holders refer to a few major sanctuaries. Big cities like Athens had several major sanctuaries, but the inscriptions only commemorate the key-holders of one or two cults. The 
exclusive and prestigious office of key-holder, as attested for some sanctuaries, is a phenomenon that was restricted to few cities and sanctuaries.

The names of key-holders are recorded in inscriptions after the names of the priests. The order of the offices implies a ranking in their importance. Therefore, the office of key-holder was a significant office, as the demos of Athens, Lagina, and Panamara honoured several key-holders. The context, in which the key-holders are mentioned, differ from city to city. The inscriptions from Athens, Delos, Lagina, Panamara, and Stratonikeia honour the noble background of key-holders. The epigraphic sources from these cities emphasize the high-ranking cultic and political offices the key-holders and their families occupied. The inscriptions from Olympia differ in many respects, as the key-holders are listed alongside low-ranking cultic officials and the inscriptions do not tell us something about their families and social status.

Due to the scope of this paper, only seven inscriptions dating to the Roman and Imperial periods will be discussed: IG II $^{2} 4480$ and IG II $^{2} 3704$ (Asclepius and Hygeia); IG $\mathrm{II}^{2} 3644$ and SEG 42:157 (Egyptian deities); IvO 66 (Zeus), I.Smyrna 753 (cult association to Apollo, Artemis, Men, Zeus, Plouto Helios, and Kore Selene); IG II ${ }^{2} 4841$ (Hera); IG IV ${ }^{2}, 1$ 297 and IG IV 768 (hero). These inscriptions reveal the gender, appointment process, social and cultic status, and partially the tasks of key-holders.

Eight inscriptions from Athens dating from the 2nd century BCE to 3rd century $\mathrm{CE}$ dedicated by the boule and the demos honour the priests and kleidouchoi of Asclepius and Hygeia. ${ }^{91}$ IG II ${ }^{2} 1944$ is the only inscription about the key-holders of Asclepius that is dated to 4th-1st centuries BCE. As the inscriptions from earlier periods do not mention key-holders, the office of key-holder was created in the 2nd century BCE or did not have the same significance in earlier periods. One of the earliest epigraphic sources for kleidouchoi of Asclepius at Athens is IG II $^{2} 974$ (137 BCE) that honours the son of Nikokrates from Phlya, who served as a priest of Asclepius and Hygeia. The priest of Asclepius at Athens was selected for an annual term (IG II ${ }^{2}$ 974, line 2; IG II ${ }^{2}$ 975, line 3). The kleidouchos was presumably also appointed for a year. The priest appointed his son, ${ }^{92}$ a relative, ${ }^{93}$ or somebody else to kleidouchos. Aleshire states that the son of a male relative was appointed to kleidouchos if the priest of Asclepius at Athens did not have a son or a son of suitable age for the office. ${ }^{94}$ IG $_{\text {II }}{ }^{2} 4456$ (line 2) dating to 110-100 $\mathrm{BCE}$ records that Zenon Meliteus was a priest of Asclepius and Hygeia, and the keyholder was the son of Leonides. IG II $^{2} 4480$ (lines 1-2, 5-6) dating to the 1st century CE provides another example for a key-holder who was not the son of the priest of Asclepius. Asopodoros, the son of Cleomenes from Phlya, was the priest, and the kleidouchos was the son of Socrates from Phlya (IG $\mathrm{II}^{2} 4480$ ). The kleidouchos was probably a relative of the priest, as both are from the deme Phlya.

\begin{tabular}{|c|c|}
\hline 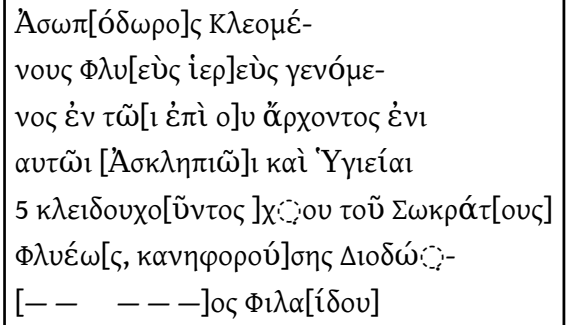 & $\begin{array}{l}\text { Asopodoros, son of Kleomenes } \\
\text { from Phlya, was the annual priest of } \\
\text { Asclepius and Hygeia, } \\
\text { in the year of the archonship, } \\
\text { the kleidouchos was - ]choc, son of Sokrates, } \\
\text { from Phlya, the kanephoros was Diodo- } \\
\text { [-- - - - ]os from Philadorai }\end{array}$ \\
\hline
\end{tabular}

IG II $^{2} 4480$ 
II $^{2} 1944$ mentions the names of three kleidouchoi and fire-carriers who were not the sons of the priest of Asclepius at Athens: Menandros, the son of Kallippos (lines 15-16), Archestratos, the son of Ameipsios (lines 19-22), and Heliodoros, the son of Olynpiodoros (lines 30-32). The cult of Asclepius at Athens had more than one kleidouchos. Inscriptions, which honour single families, mention a single kleidouchos who was a member of the same family. Inscriptions, which list several cultic officials who had an office for the same period, mention several kleidouchoi. According to Hubbe, the priest appointed his son to kleidouchos and fire-carrier in order "to be free to devote his attention to the sacred property". ${ }^{95}$ The sanctuaries of Asclepius as centres of healing were visited by many people. Rituals and cures were performed on a daily basis. The priests of major sanctuaries of Asclepius, such as those at Athens, Epidaurus, Cos, or Pergamon, needed several cultic officials for the performance of different rituals and therapies. For the division of the tasks, it was not necessary that the priest of Asclepius appointed his son. The priest could also appoint somebody else to key-holder, as attested for the cult of Asclepius at Athens. The kleidouchoi of Asclepius at Athens were not little children, but teenagers or young men who were able to perform rituals on a daily basis. From IG II ${ }^{2} 974$ (line 23), we learn that the priest of Asclepius appointed his son Dios to kleidouchos. The word after $\kappa \lambda \varepsilon 1 \delta$ oṽ Xov $\kappa \alpha\left[\grave{l}\right.$ is missing. IG II ${ }^{2} 1944$ (1st century BCE) mentions kleidouchoi who were also fire-carriers ( $\pi$ ú $\varphi \circ \rho \circ \varsigma$ - purphoros/ pyrphoros). ${ }^{96}$ After the restoration, the lines $23-24$ (IG II ${ }^{2}$ 974) can be translated as following: appointed his son Dios to kleidouchos and fire-carrier for all therapies, which took place every day. ${ }^{97} \mathrm{Hubbe}$ has suggested that the term $\theta \varepsilon\left[\rho \alpha \pi \varepsilon i \alpha_{\alpha}\right.$ (therapeias) mentioned in line 24 refers to worship that included prayers "for health in general, or to be cured". ${ }^{98}$ Aleshire states that the key-holders acted as temple guardians and their duties included "not only incubation and the healing of the sick, but also the dedication of votives". ${ }^{99}$ The epigraphic sources are silent concerning the different tasks of kleidouchoi.

Aelius Aristides tells us that the temple keeper of the sanctuary of Asclepius at Pergamon locked and unlocked the temple door and helped worshippers with their therapies (Sacred Tales 1.11, 2.35). Aelius Aristides mentions the time of the holy lights (Sacred Tales 1.11). According to Schröder, the holy lights refer to rituals performed twice a day in the temple. ${ }^{100}$ The rituals were performed at sunrise and sunset. The Greek temples were generally oriented eastward. The cult statue was set up in the west of the temple and the door in the east. The temple door was opened at sunrise so that the first rays of the rising sun entered through the open door and illuminated the cult statue. The kleidouchos opened the temple door in the morning and closed in the evening. IG XII, 4, 346 (lines 9-10) from Cos dates to the 1st century BCE and mentions that the priestess of Artemis Pergaia should open the sanctuary ( $\tau \grave{\alpha}$ i $\varepsilon \rho \alpha ́$ ) at sunrise and burn incense in the temple. We also learn from IG XII, 4, 346 (line 9) that the sanctuary was only opened on customary days, indicating that the sanctuary was not opened every day. IG XII, 4, 1, 295 from Cos dates to the 1st century BCE and concerns the sanctuary of Asclepius. IG XII, 4, 1, 295 (line 12) mentions that the priest should open the temple ( $\dot{o}$ voò $\varsigma$ ) every day. The temple was presumably opened at sunrise. The two inscriptions from cos illustrate that some sanctuaries were opened every day and some on customary days. For ancient Greeks, the cult statues represented and showed

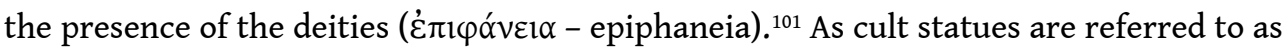
deities, the access to the temple meant access to the presence of a deity. Having the 
temple key meant in this context that the kleidouchos had access to the presence of the god and was probably involved in the performance of rituals in the temple. As cultic officials performed the rituals for the cult and for the sake of the whole community, the cultic officials, especially those with high status, should be from aristocratic families, as they were considered well-born and to have virtues. ${ }^{102}$ The inscriptions from Athens, Delos, Lagina, and Panamara illustrate that the families of key-holders belonged to the wealthy families and occupied significant political and cultic offices for generations. This is also the period at which the wealthy families emphasized in inscriptions their noble background and the prestigious cultic and political offices their family members occupied over generations. The office of key-holder was one of the prestigious offices mentioned in inscriptions.

IG II 3704 (lines 1-4) from Athens dating to 225-235 CE was dedicated by the boule in honour of Quintus Statius Themistocles from Cholleidai, who was the son of the priest of Asclepius Soter and descended from philosophers, consuls, and Asiarchs (IG II ${ }^{2} 3704$, lines 2-10). People from wealthy and leading families of the city were appointed to consuls and Asiarchs. Titus Flavius Glaukos from Marathon, a relative of Quintus Statius Themistocles, served as kleidouchos of Asclepius (IG II ${ }^{2} 3704$, lines 11-14). The social background of Titus Flavius Glaukos indicates that the office of kleidouchos of Asclepius at Athens was a prestigious office reserved for the members of leading families of the city who occupied high-ranking political and cultic offices. IG II ${ }^{2} 974$ (lines 9-17, 28-33) and IG II ${ }^{2} 975$ (lines 4-12) mention that the priests of Asclepius at Athens made several sacrifices to Asclepius and to other deities and were generous towards people. This was a highly costly matter, and only wealthy families had the financial means to do it.

\begin{tabular}{|c|c|}
\hline 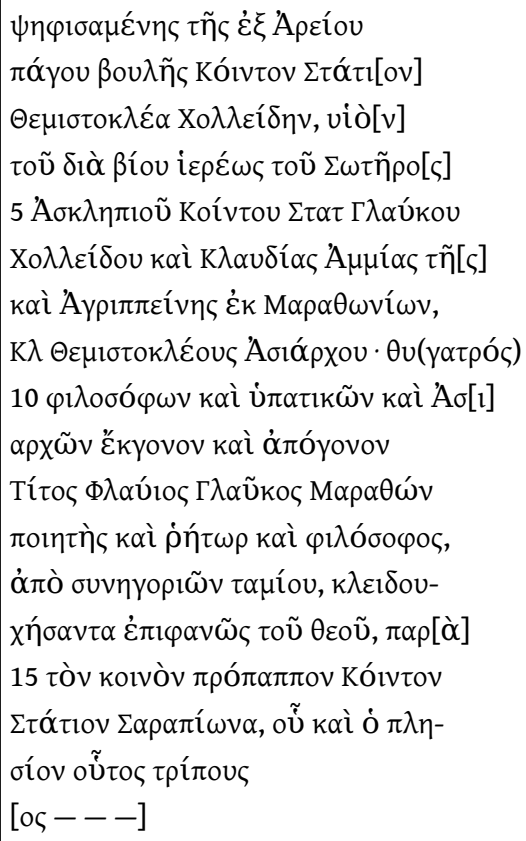 & $\begin{array}{l}\text { By decree of } \\
\text { of the Areopagus, to Quintus Statius } \\
\text { Themistocles from Cholleidos, son } \\
\text { of the priest for life of Asclepius } \\
\text { Soter, Quintus Statius Glaukos } \\
\text { from Cholleidos and Claudius Ammia } \\
\text { and Agrippina of Marathon, daughter } \\
\text { of Claudius Themistocles, Asiarch, } \\
\text { descended and born of philosophers and } \\
\text { consuls and Asiarchs, } \\
\text { Titus Flavius Glaukos of Marathon, } \\
\text { poet and orator and philosopher, } \\
\text { advocatus fisci, was a kleidou- } \\
\text { chos with distinction of the god beside his } \\
\text { common great-grandfather Quintus } \\
\text { Statius Sarapion, and whose } \\
\text { nearby tripod }\end{array}$ \\
\hline
\end{tabular}

IG II $^{2} 3704$

39 At least four inscriptions from Athens mention the kleidouchoi of the Egyptian deities. ${ }^{103}$ Apart from SEG 42:157 (116-95 BCE), the other inscriptions date to the 1st-3rd centuries CE. Dunand has suggested that the office of kleidouchos of the Egyptian deities is only 
attested by epigraphic evidence for Athens and Delos. ${ }^{104}$ There is a single inscription from Side (IK Side I 17) dating to the 2nd-3rd century CE that was dedicated to a keybearer of Isis and Serapis. The key-holder mentioned in IK Side I 17 is called $\kappa \lambda_{1}$;

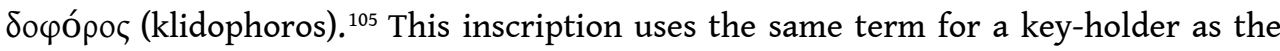
inscriptions on the kleidophoroi of Hecate at Lagina. IK Side I 17 is a short inscription that does not describe the task of the key-holder. The kleidophoros of the Egyptian deities at Side had probably similar tasks as the key-holders of the Egyptian deities at Athens or on Delos. Delos was under the Athenian rules, and Athens determined the features of the cult and appointed the priests and kleidouchoi of the Egyptian deities on Delos. The cult of the Egyptian deities was introduced in Athens in the second half of the 4th century BCE. The late epigraphic record of kleidouchoi of the Egyptian deities is linked to the late beginning of the epigraphic record of kleidouchoi at Athens. We do not know whether the office of kleidouchos existed from the beginning of the cult of the Egyptian Deities at Athens and on Delos. If it was a prestigious office and existed from the beginning of the cult, we may expect its record in inscriptions dating to the 4th2nd centuries BCE. Probably, the office of kleidouchos was established under the influence of the office of kleidouchos of Asclepius at Athens. The inscriptions do not describe the tasks of the kleidouchoi of the Egyptian deities at Athens but list the names of different cultic officials and the names of their fathers. The priests as well as the kleidouchoi were all men. In contrast to the kleidouchoi of Asclepius, the kleidouchoi of the Egyptian deities were not the sons of the priests. We learn from SEG 42:157 that Menandros from Alopeke was the priest, Asopokles from Phyla was the kleidouchos, and Sosikratos from Laodikea was the attendant of the Egyptian deities at Athens. The three cultic officials were from different cities. ${ }^{106}$ The kleidouchos mentioned in SEG 42:157 was from Athens and was not the son of the priest. The names of the kleidouchoi of the Egyptian deities at Athens are mentioned in inscriptions after the names of the priests. It seems that the kleidouchos did not have the same standing as the priest, but his office was the most significant after the office of the priest.

\begin{tabular}{|c|c|}
\hline 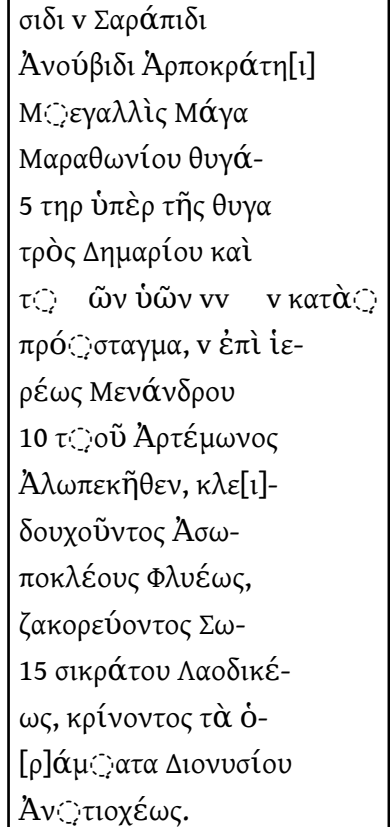 & $\begin{array}{l}\text { To Isis, Sarapis, } \\
\text { Anoubis, Harpokrates } \\
\text { Megallis, the daughter of Maga } \\
\text { from Marathon, dedicated } \\
\text { on behalf of her daughter } \\
\text { Demarion and } \\
\text { her sons, according to } \\
\text { the command, during the } \\
\text { priesthood of Menandros, } \\
\text { the son of Artemon from } \\
\text { Alopeke, the klei- } \\
\text { douchos was Aso- } \\
\text { pokles from Phlya, } \\
\text { attendant was So- } \\
\text { sikratos from Laodikea, } \\
\text { judge of spectacles was } \\
\text { Dionysius from } \\
\text { Antioch }\end{array}$ \\
\hline
\end{tabular}


SEG 42:157

IG II ${ }^{2} 3564$ (1st/2nd century CE) from Athens was dedicated by the boule and the demos to Philion, who was a kleidouchos of Isis and Sarapis. The inscription also mentions the names of the priest, attendant, and canephoros who were from different families. They may be relatives even if they were from different families. IG II $^{2} 3644$ (2nd century CE) was dedicated to the son of Aurelius Zosimus, who was a kleidouchos of the Egyptian deities. The family of Aurelius Zosimus had handed down from generation to generation the cultic offices, indicating that his family was very influential and involved in cultic life of the city. As most prestigious offices were preserved for the members of leading families of the city, the office of kleidouchos of the Egyptian deities at Athens was also a prestigious office.

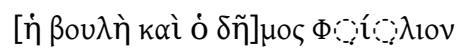

$[---\quad---\kappa \lambda] \varepsilon 1 \delta o u x \eta ́ \sigma \alpha v \tau \alpha$ Ë̌-

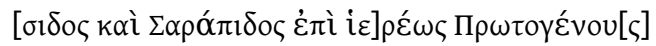

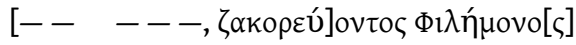

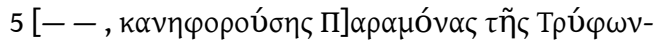

[os-- - ]

IG II 3564

boule and demos [dedicated] to Philion

[- - - was kleidouchos of Isis

and Sarapis during the priesthood of Protogenos

[- - - attendant was Philemon

5 [ - kanephoros was Paramona, the daughter of Tryphon

$[---]$

\begin{tabular}{|c|c|}
\hline 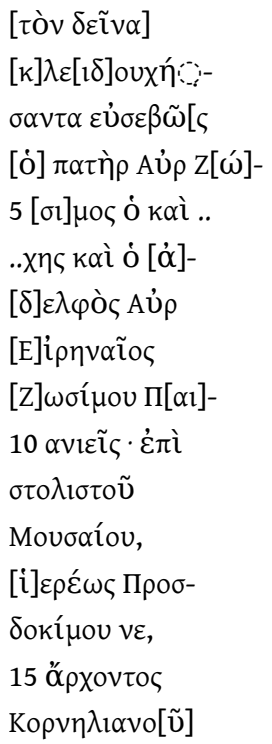 & $\begin{array}{l}\text { was kleidouchos } \\
\text { piously, } \\
\text { his father Aurelius Zo- } \\
\text { simus and } \\
\text {... and } \\
\text { his brother Aurelius } \\
\text { Irenaeus, } \\
\text { the son of Zosimus from Paia- } \\
\text { nia. In the year when } \\
\text { Mousaeus was } \\
\text { the stolistes }{ }^{107} \\
\text { Prosdokumos was } \\
\text { the priest } \\
\text { Cornelianus was } \\
\text { the archon }\end{array}$ \\
\hline
\end{tabular}

IG II 3644

41 According to Dunand, the main task of kleidouchoi of the Egyptian deities consisted of opening and closing the temple door during the daily ceremonies. ${ }^{108}$ Podemann Sørensen states that „bringing light into dark rooms was an essential feature of Egyptian temple ritual". ${ }^{109}$ The kleidouchoi of the Egyptian deities unlocked the temple door in the morning and showed the cult statue to the worshippers, ${ }^{110}$ meaning that the daily ceremony was celebrated with the worshippers early in the morning. The temple 
door was unlocked and opened solemnly by the kleidouchos so that the light of the rising sun can illuminate the cult statue, and the worshippers can see it. As Podemann Sørensen emphasizes, the daylight was brought into the darkness of the temple that housed the cult statue, and "a cycle of latent and manifested life" ${ }^{111}$ The kleidouchos of the Egyptian deities did not have the same standing as the priest, but his office was significant, as he was part of these rituals marking the beginning with unlocking the temple door, and the end with locking. The rituals in the morning and evening were crucial, as they marked the beginning and the end of rituals performed in the temple. As the key-holders are not attested for all sanctuaries of the Egyptian deities, these rituals were performed by the priests or other cultic officials.

IvO 66 (50 BCE) from Olympia lists cultic officials of the sanctuary of Zeus at Olympia. The priest of Zeus is not mentioned in this inscription. The first cultic official mentioned in this inscription is the flute-player followed by the kleidouchos, adviser, wine-pourer, epispondorchestes, and the cook. The kleidouchos is also mentioned after the flute-player in IVO 65 (line 17) and IVO 62 (line 10). IVO 69 (line 19) mentions the kleidouchos after the seers, flute-player, and secretary. IvO 64 (line 14) lists the names of three kleidouchoi after the seer. Only IvO 61 mentions the kleidouchos at the beginning of the inscription. The adviser, secretary, flute-player, epispondorchestes, ${ }^{112}$ and kanephoros are mentioned after the kleidouchoi in the same inscription (IvO 64). It cannot determined whether the kleidouchoi had a higher standing than other cultic officials mentioned in these inscriptions, as the order of offices is not constant. IvO 61, 62, 64, and 65 illustrate that the cultic officials were all from different families. The kleidouchos was not the son of the priest and not appointed for life, but for a period.

\begin{tabular}{|c|c|}
\hline$\left[\alpha u ̉ \lambda \eta \tau \eta^{\prime} \varsigma\right]$ & flute-player was \\
\hline $1 \Lambda \varepsilon \omega v i ́ \delta[\alpha \varsigma-----]$ & Leonidas ----- ] \\
\hline$\kappa \lambda \varepsilon 1 \delta \circ \tilde{}[\chi \circ \varsigma,--] \alpha \varsigma$ & kleidouchos - - - \\
\hline 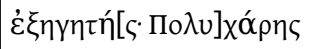 & adviser was Polychares, \\
\hline oiv[oxó]os & wine-pourer was \\
\hline 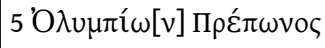 & Olympion Preponos, \\
\hline 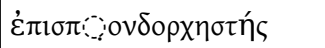 & epispondorchestes was \\
\hline 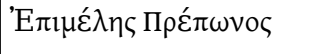 & Epimeles Preponos, \\
\hline 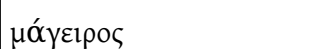 & cook was \\
\hline 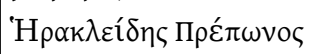 & Herakleides Preponos \\
\hline
\end{tabular}

IvO 66

Apart from IvO 64, all inscriptions mention a single kleidouchos, suggesting that at least one cultic official was in charge of the keys at the sanctuary of Zeus in Olympia. Zoumbaki has suggested that the kleidouchoi of the sanctuary of Zeus at Olympia were not only in charge of the temple key but also of numerous thesauroi, which housed precious votives. ${ }^{113}$ The sanctuary of Zeus was one of the major Pan-Hellenic sanctuaries that had twelve treasury houses. As the treasury houses at Olympia were built between 600 and $450 \mathrm{BCE}$, we can assume that the priest or another cultic official was in charge of the keys. The record of kleidouchoi of the sanctuary of Zeus at Olympia began in the second half of the 1st century BCE. This means that more than 300 years later after the last construction of a treasury house. It should be noted that the 
inscriptions from Olympia do not mention whether the key-holder was in charge of all keys or only of certain buildings, e.g. the temples.

The inscriptions from Olympia are silent concerning the tasks of the key-holders. As the sanctuary had numerous officials who were in charge of different tasks, the responsibility of the key-holder was limited to the keys of the sanctuary and to a few other tasks. The inscriptions mentioned here give the impression that the key-holder did not have a high-ranking cultic status or a special position that distinguished him from other cultic officials listed in these inscriptions from Olympia. Zoumbaki states that some of the kleidouchoi were members of well-known families. ${ }^{114}$ There is no evidence that all or most key-holders of this shrine were from well-known families. The key-holders are mentioned together with epispondorchestes and oinochooi who were slaves and had low-ranking offices. ${ }^{115}$ For this reason, it seems likely that the office of key-holder was not reserved to people from the upper-class as the key-holders of Asclepius at Athens or those of Hecate at Lagina. Therefore, the erection of stelai bearing the names of these cultic officials emphasizes the significance of these offices for the sanctuary of Zeus at Olympia, but not their high cultic status. The key-holders of the sanctuary of Zeus at Olympia had probably similar cultic status as the aeditui. Several iron temple keys found in the sanctuary of Zeus in Olympia may have been dedicated by the key-holders, priests, or worshippers (Fig. 7). Their simple mechanism suggests that these keys were not used for the temples or treasury houses.

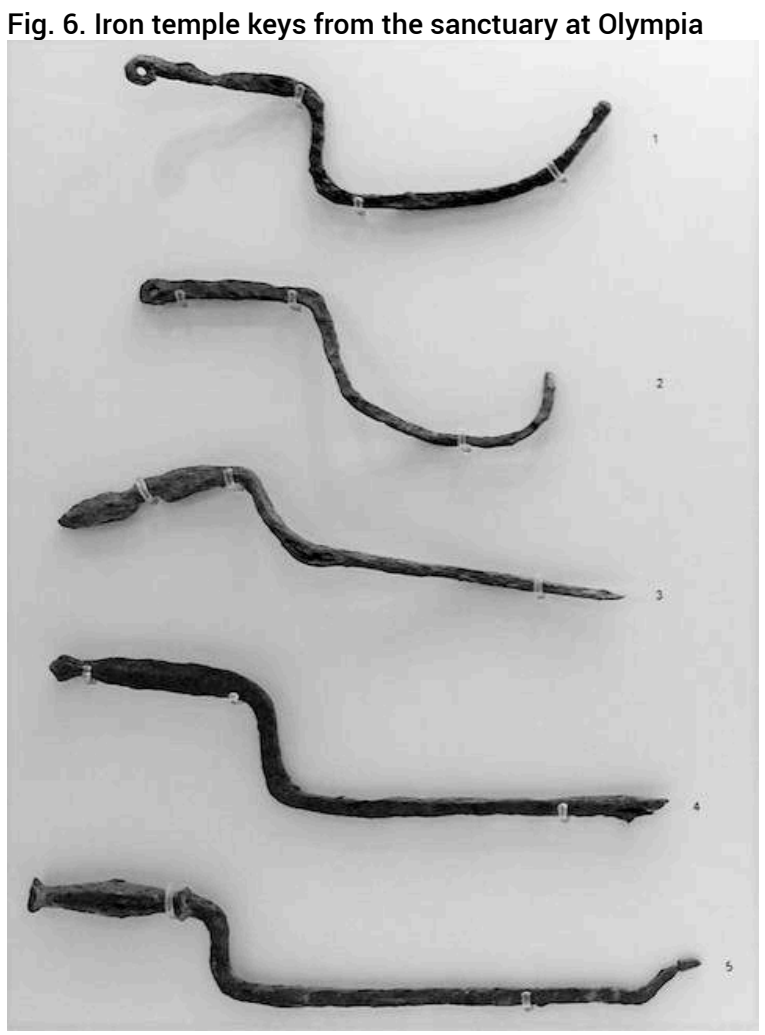

Courtesy of the Archaeological Museum of Olympia; photo by author

An inscribed stele from Smyrna dating to the 1st century CE was dedicated by a cultic association to Apollo, Artemis, Men, Zeus, Plouto Helios, and Kore Selene (I.Smyrna 753, lines 24-26). The inscription says that a gilded key was carried in a procession (pompe). 
The key was probably carried by a priest or a cultic official who was in charge of the temple key. Thompson believes that the key was carried by a kleidouchos in a procession, and money was collected for a temple. ${ }^{116}$ The term $\lambda$ oyía (logia) means 'collection' and refers here to the collection of money for the cult association. Cultic officials collected money for the sanctuary in processions or visited households for this purpose. ${ }^{117}$ Money collected at ritual begging was called ó $ү \varepsilon p \mu o ́ \varsigma$ (agermos) and is attested for the cults of various deities, e.g. Demeter (LSCG 175, line 12), Artemis (Hdt. 4.35.3), Zeus, and Cybele in Greek East. ${ }^{118}$ Ritual begging is also attested for Argos, where the priestess of Hera collected money (Aesch. Xantriai; scholia on Aristoph. Frogs 1344; Plat. Rep. 2.381d). LSCG 175 (line 12) concerns the cult of Demeter on Cos and mentions ritual begging as one of the revenues of the sanctuary, indicating that ritual begging was practiced on a regular basis (HGK 17 and IG XII,4 1:356). I.Smyrna 753 can also refer to ritual begging practiced regularly. Robertson has suggested that ritual begging is linked to human fertility. ${ }^{119}$ Even if the deities mentioned in I.Smyrna 753 are associated with human fertility, the aim of the collection of money is not indicated. A cult object carried at ritual begging by cultic officials symbolised the cult or the sanctuary. ${ }^{120}$ The gilding of the key mentioned in I.Smyrna 753 suggests that the key was not intended to be used as a temple key but escorted in processions as a symbolic cult object, which was used as an insignia of the sanctuary and for rituals. I.Delos 1444 (141 BCE) mentions that the kleidouchos carried an inscribed silver key whose end was shaped as a lion (see also I.Delos 1443). The inscribed bronze key found in the sanctuary of Artemis in Lousoi may also have been carried in processions. The key mentioned in I.Smyrna 753 had presumably the shape of a temple key. Apart from the significance of the temple key as an insignia of priestly status, the temple key is much bigger than the Laconian key (Fig. 2). The key from Lousoi has a length of $40,5 \mathrm{~cm}$, whereas the Laconian keys have a length of less than $20 \mathrm{~cm}$. Nowadays, some sacred objects, which are escorted in processions, have a considerable size. Depending on the number of worshippers who attend the procession, the size allows worshippers to see the sacred objects. The same practice was probably also applied in antiquity.

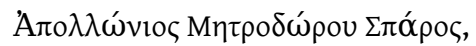

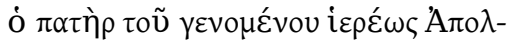

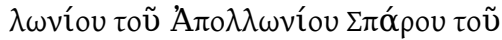

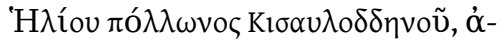

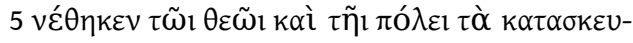

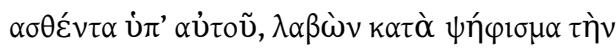

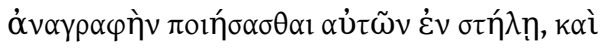

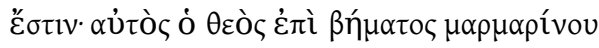

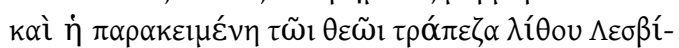

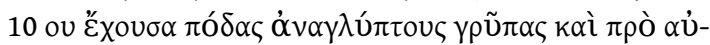

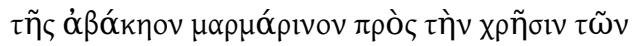

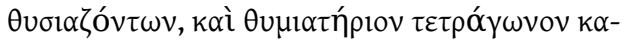

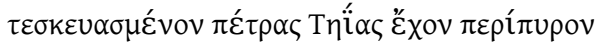

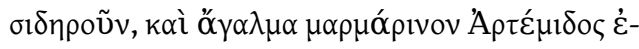

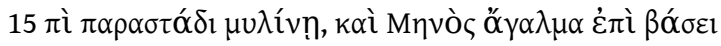

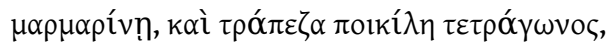

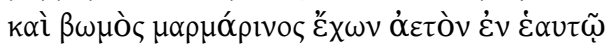

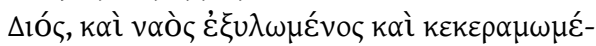

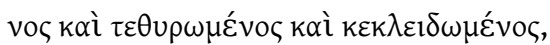

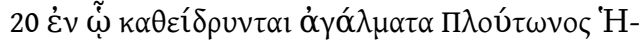

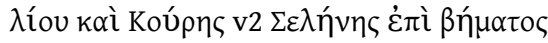




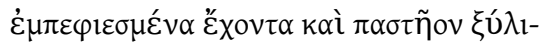

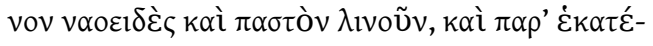

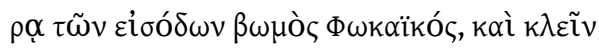

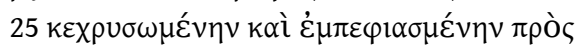

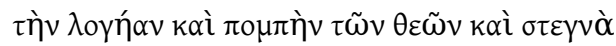

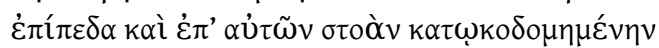

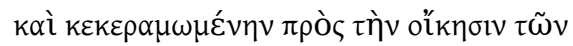

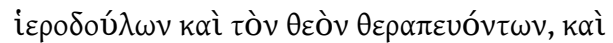

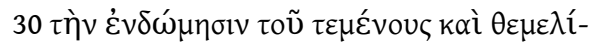

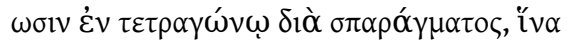

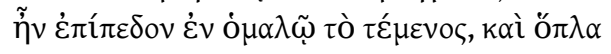

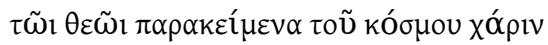

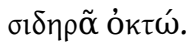

I.Smyrna 753

Apollonios Sparos, son of Metrodoros father of the former priest Apollonios, son of Apollonios Sparos, priest of Helios Apollo Kisauloddenos, 5 set up as a dedication to god and to the city the things provided by him, having received permission by decree to inscribe them on a stele. They are the following: God himself on a marble pedestal. Adjacent to God a table of lesbian stone 10 with sculptured feet of a griffon and before it a marble dish to use for sacrificing and a square incense-altar, made of stone from Teos, with an iron vessel containing fire. Alongside, a marble statue of 15 Artemis on a millstone stand. A statue of Men on a marble base along with square, many-colored table. A marble altar with an eagle on it, of Zeus. A temple of wood with tiled roof and locked doors, 20 in which are dedicated clothed statues of Pluto Helios and Koure Selene upon a pedestal, holding a wooden case in the form of a shrine and a linen embroidered bridal curtain. On each of the entrance of Phokaian altar. A key, 25 gilded and covered for the collection and procession of the gods. Closely-fitted flat pavement stones and on them a stoa built up and roofed with tiles for housing the sacred slaves and servants of god. $30 \mathrm{~A}$ wall enclosing the temenos and a foundation squared by means of chips of stone, so that the temenos would be on level ground. Shields adjacent to God for ornamentation, made of iron, in number, eight.

I.Smyrna 753; translation by L.L. Thompson 2007, 102-103.

Two inscribed taurobolic altars, which have the same size, were found in 1862 at the same place in Athens. ${ }^{121}$ The inscriptions on the two altars reveal that one of the altars was dedicated by Mousonius (IG II ${ }^{2} 4842$ ) and the second by Archeleos (IG II ${ }^{2}$ 4841). The altar of Mousonius is dated to $386 / 7 \mathrm{CE}$, as the inscription reveals that he celebrated the taurobolium in Athens at the beginning of the consulate of Honorius and Euodius, and during the archonship of Hermogenes. The altar of Archeleos is dated to 361-387 CE. ${ }^{122}$ The relief on the altar dedicated by Archeleos depicts Rhea and Attis as an enthroned couple, a man with a torch standing on the left-hand side, and a woman with two torches on the right-hand side. According to Sfameni Gasparro, the iconography of the altar of Archeleos associates Cybele with the Eleusinian Demeter. ${ }^{123}$ The taurobolium was performed in honour of the Mother of Gods. Rhea was also called 'Mother of Gods' and was identified with Cybele during the Roman period. The inscription IG $\mathrm{II}^{2} 4841$ reveals that Archeleos was from Athens, lived in Argos, and dedicated a taurobolium to Attis and Rhea. ${ }^{124}$ The inscription also reveals that Archeleos introduced the rites of taurobolium in Athens, was a dadouch of Kore at Lerna, and carried the key of Hera at Argos (IG II ${ }^{2} 4841$, line 10). According to Saradi and Eliopoulos, Archeleos was a keyholder of Hera. ${ }^{125}$ Archeleos does not mention that he was a cultic official of Hera. The

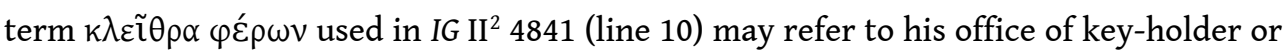
to a procession, at which he carried the key. Written sources on key-holders discussed 
in this paper show that the key-holders were not appointed for a procession, but for a period. This would mean that Archeleos was also appointed for a period as a keyholder. As Archeleos mentions his most prestigious offices in this short inscription, the office of key-holder of Hera at Argos was an office of high status. Saradi and Eliopoulos state that the cult of taurobolium became highly popular in the 4th century CE among aristocrats. ${ }^{126}$ Sironen believes that the dedicator of an inscribed statue base (IG IV 1608) dating to 379-382 CE from Argos is identical with Archeleos mentioned in IG $\mathrm{II}^{2}$ $4841 .{ }^{127}$ Such a dedication suggests that Archeleos was a member of a wealth family and had cultic offices, which were reserved to the members of leading wealthy families.

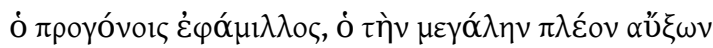

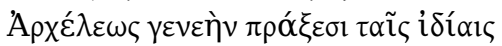

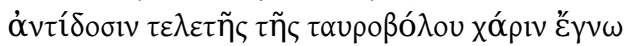

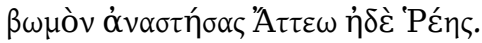

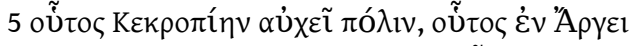

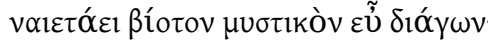

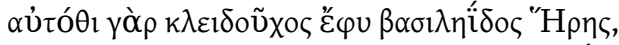

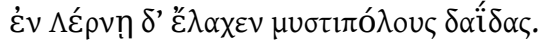

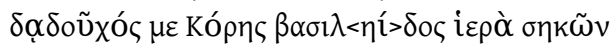

10 "Н

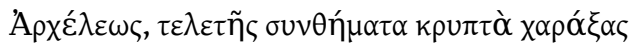

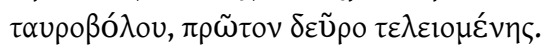

IG II $^{2} 4841$

The rival of his ancestors, who elevated his great

family even more by his own actions, Archeleos,

knew gratitude in return for the rite of the taurobolium,

having set up an altar of Attis and Rhea.

$5 \mathrm{He}$ is the pride of the Kekropian city; he dwells in Argos

living a mystic life well,

for there he is keyholder of Queen Hera,

and in Lerna he received the torches that solemnize the mysteries.

As dadouch of Kore, carrying the sacred

10 keys of Queen Hera's shrine,

Archeleos dedicated me, this altar, to Rhea,

having engraved hidden tokens of the taurobolium rite, performed here for the

first time

IG II $^{2}$ 4841; translation by Stephen Lambert, https://www.atticinscriptions.com/

inscription/IGII25/13252

A coin (370-350 BCE) from Argos depicts on one side the head of Hera and on the other side a temple key (Fig. 7). Presumably, the key functions here as an attribute and represents Hera as the key-holder of Argos. The main deity of a city is usually not depicted as a key-holder of the city. Athena is invoked in Aristoph. Thesm. 1140-1142 as the key-holder of Athens. Epigraphic, literary, and iconographic material does not provide further evidence for Athena as the key-holder of Athens, ${ }^{128}$ or Hera as the keyholder of Argos. If Archeleos carried the key of Hera in a procession, as mentioned in IG $\mathrm{II}^{2} 4841$, this key may have been the key of the temple of Hera at Argos, or a symbolic key of Hera. The key depicted on the coin may refer to a symbolic key of Hera. More than ten bronze keys were found at the sanctuary of Hera at Argos. ${ }^{129}$ Baumbach has suggested that the keys were dedicated around the same period as the coin from Argos. ${ }^{130}$ The bronze keys were probably dedicated by cultic officials of Hera at Argos. IG II $^{2}$ 4841 is, however, the only epigraphic evidence for a key-holder of Hera at Argos. IG IV 
642 from Argos engraved on an orthostat of a temple (2nd century BCE) uses the term

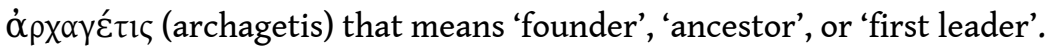

Fig. 7. Coin from Argos depicting Hera on one side and a temple key on the other side
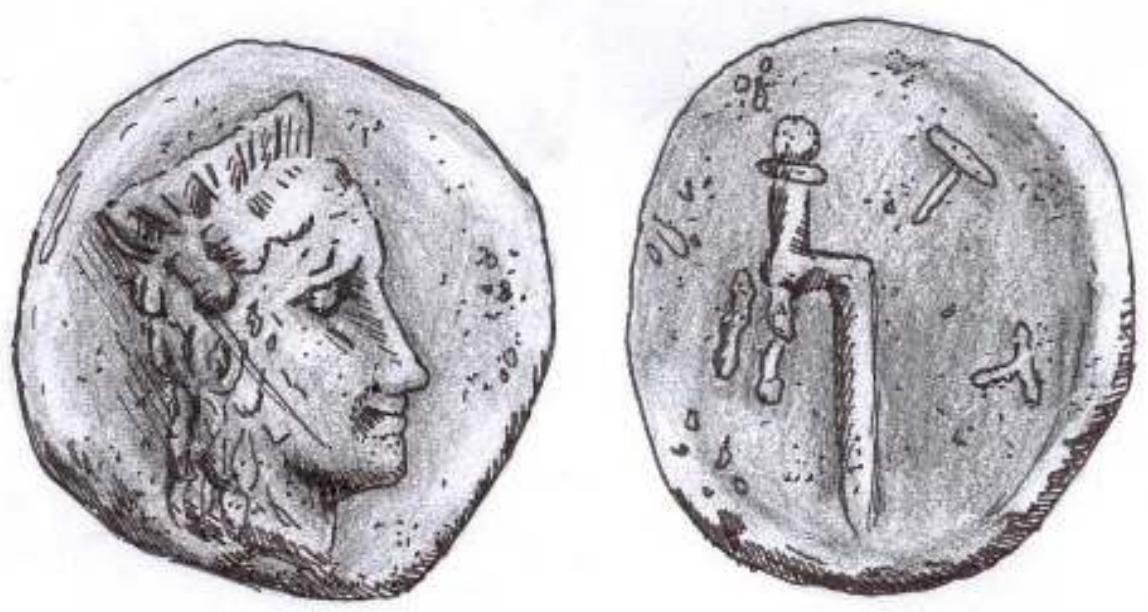

Imhoof-Blumer 1883, 174, fig. 96

This term, which is a feminine noun, refers generally to deities. The name of the deity is not indicated, and the name of the woman is missing, since the part of the

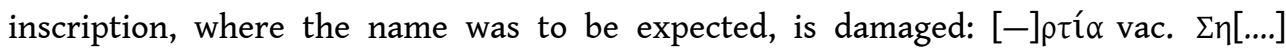

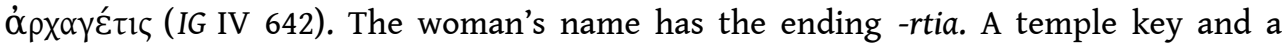
sceptre engraved on this orthostat suggest that it was dedicated to a priestess. This orthostat has similarities with the grave altars IG VII 2676 and 2021, which bear a short inscription and depict a temple key. IG VII 2676 says that it was dedicated to Noumides,

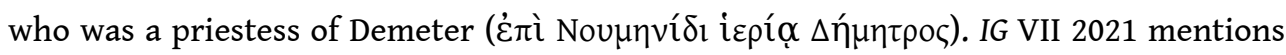
the name $\Theta \varepsilon o \mu v \alpha ́$ ó $\alpha$ (Theomnasta), meaning that the altar was dedicated to a priestess named Theomnasta (see also Table 2). IG IV 642 does not indicate whether the priestess served at the sanctuary of Hera in Argos. Mythical figures are also mentioned as keyholders of Hera at Argos. Aeschylus says that Io was the key-holder of Hera at Argos (Supp. 291). Clement of Alexandria tells us that Callirhoe was the kleidouchos ( $\kappa \lambda \eta 1 \delta$ oṽ $о \varsigma$ ) of the temple of Hera at Argos (Strom 1.24). The accounts of mythical keyholders of Hera at Argos do not necessarily imply that the office of key-holder at Argos has a long tradition.

Some inscriptions refer to heroes and daemons who were called key-bearers. Single inscriptions dating to the 3rd century BCE from Troizen (IG IV 768, line 2) and Epidaurus (IG IV $\left.{ }^{2}, 1297\right)$ were dedicated to heroes who have the title 'klaikophoros' (keybearer). Wilhelm mentions that the inscription $I G I^{2}, 1297$ was found in the sanctuary of Asclepius. ${ }^{131}$ Both inscriptions bear the same inscription: Hero klaikophoros. Legrand states that keys were associated with deities and heroes who were linked to the netherworld. ${ }^{132} \mathrm{~A}$ funerary inscription of a young man found at Teos mentions that the kleidouchos ( $\kappa \lambda \eta \delta o v ̃ x o v)$ demon ( $\delta \alpha i ́ \mu \omega v)$ took him from life (CIG 3123, line 7). Demons were not the same as heroes, but were also linked to the underworld. The inscriptions 
from the Peloponnese suggest that the concept of key-holders was already projected in the 4th century BCE on mythical figures linked to the netherworld. Further research is needed to clarify why mainly chthonian deities and heroes were called key-holders. Kearns has suggested that the title klaikophoros refers to the task of heroes as "doorkeeper or guardian of the sanctuary" ${ }^{133}$ Kearns compares hero klaikophoros with Hecate as protector of the gates. ${ }^{134}$ Pausanias (9.19.5) says that Heracles, who was a hero, closed the sanctuary of Demeter at Mycalessus (Boeotia) at night and opened it presumably in the morning. Heracles functions here as a key-holder of the temple of Demeter, but not as a guardian who protected the entrance of the temple. Images of Hecate were set up at the house doors for their protection against evil. ${ }^{135}$ Similarly, a stele or an altar bearing the inscription 'hero klaikophoros' may have been placed at the entrance of the temenos for the protection of the shrine. IG V,1 1447 from Messene (191 BCE) is engraved on a marble stele that measures $37 \times 52 \mathrm{~cm}^{136}$ and mentions a klaikophoros (line 11). ${ }^{137}$ Wilhelm believes that the klaikophoroi mentioned in this inscription refer to heroes as the inscription from Epidaurus. ${ }^{138}$ It seems more likely that the klaikophoroi refers to cultic officials, as IG V,1 1447 was a sacrificial calendar. The task of the klaikophoroi was presumably mentioned in the missing part of the line.

"H

ท̆

\section{Hecate as divine key-holder and her festival of the key}

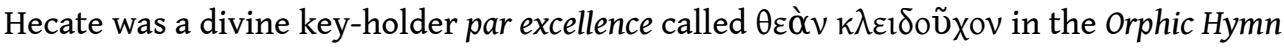
to Hecate 7. In the early Greek literature, Hecate was not characterised as a key-holder of the gates to Hades, but as a goddess of the cosmos. ${ }^{139}$ Hesiod portrays Hecate as a deity who holds privilege in earth, heaven, and sea (Theog. 425-426). Plutarch also describes Hecate as a goddess of the entire cosmos (earth, sky, sea, and netherworld), and compares her with Anubis. ${ }^{140}$ From the $6^{\text {th }}$ century BCE onwards, Hecate was closely associated with Demeter and Persephone (Hom. Hymn Dem. 25, 52, 59, 61, 438-440). She was, therefore, not represented as a guardian of the gates to Hades. Johnston states that the passage in the Hom. Hymn Dem. 438-440 is the earliest allusions to Hecate's role as a guide at times and places of transition. ${ }^{141}$ Hom. Hymn Dem. 438-441 mentions that Hecate embraced Persephone and became her companion. It is questionable whether this was an allusion to Hecate's role as a guide at times and transition. Hecate's role as a guide of transition became manifest in later periods.

51 Aristophanes says that all citizens at Athens had a little tribunal in their porch before the door similar to the altars of Hecate (Vesp. 800-804). ${ }^{142}$ Hecate was a protector of the doors. A vase from Eleusis dating to the 5th century BCE depicts a woman standing in front of the temple door and holding two torches. ${ }^{143}$ von Rudloff believes that this woman represents Hecate. ${ }^{144}$ The goddess depicted here protects the temple door that gives access to the most sacred place in her shrine. Deities were protectors of their sanctuaries and were depicted in vase paintings standing next to their temples. The goddess with two torches depicted on the vase from Eleusis may represent Demeter, Kore, or Artemis, who had a temple at Eleusis and were also depicted with torches.

52 The so-called decree of Molpoi (LSAM 50, lines 25-26, 28-29) dating to the $200 \mathrm{BCE}^{145}$

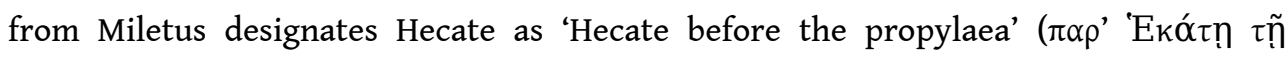

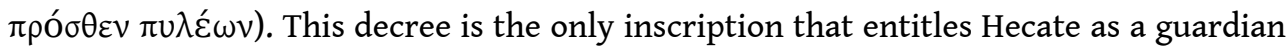


of the gates. The conception of Hecate as protector of the gates and house doors is not an allusion to her role as a key-holder of the gates to Hades in the 5th century BCE. This is a role that Hecate had to have in later periods. Hecate is praised in the PGM 4.2836 for being the key-bearing mistress of the entire cosmos and of the gates to Hades. Proclus also portrays Hecate as kleidouchos who controls the boundaries of the cosmos (In R.

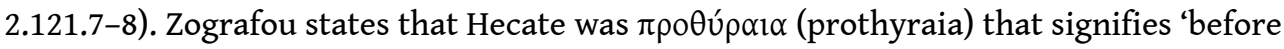
the doors'. ${ }^{146}$ The Orphic Hymn to Prothyraea is addressed to Artemis, Eilethyia, and Prothyraia (lines 12-13). Prothyraia is a goddess with several names and can also be identified with Artemis or Hecate. ${ }^{147}$ The Orphic Hymn to Prothyraia is addressed to a goddess who is linked to childbirth, women's life, and houses. The hymn mentions that Prothyraia is a kleidouchos (Orphic Hymn to Prothyraia 5). The keys mentioned here may refer to different stages of women's life and to house doors. Prothyraia was probably invoked for the protection of the entrance to the house against evil that menaced childbirth, children, and different stages of women's life.

Pausanias (2.30.2) tells us that Alcamenes created the triple form of Hecate that was set up next to Nike-Pyrgos on the Athenian acropolis. The iconography of triple Hecate holding a key is attested for the Imperial period. Statuettes and reliefs of triple Hecate holding a key are not numerous, and date to the 2nd and 3rd centuries CE. ${ }^{148}$ The triple representation is not only common for Hecate, but also for Artemis. Virgil calls Hecate and Diana 'threefold' and 'triple-faced' (Aen. 4.511). The depiction of Diana and Hecate with a key in the hand identifies both goddesses as key-holders. ${ }^{149}$

Strabo (14.2.25) mentions that there were two temples ${ }^{150}$ in the territory of Stratonikeia, and the most prominent was that of Hecate at Lagina. ${ }^{151}$ The sanctuary of

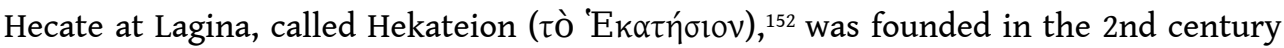
BCE. Lagina and Panamara were located in the territory of Stratonikeia, a city founded in the 3rd century BCE by Seleucids (RE IV, A1, 322). ${ }^{153}$ The sanctuary of Hecate at Lagina was linked to Stratonikeia by a processional way. ${ }^{154}$ The temple of Hecate at Lagina is dated to the 2nd-1st centuries BCE. ${ }^{155}$ I.Stratonikeia 504 (line 2) dating to 197$166 \mathrm{BCE}$ mentions a priest of Hecate. This inscription indicates that Hecate had already a sanctuary at Lagina in the first half of the 2nd century BCE. Tirpan, Gider and Büyüközer believe that an inscription dating to the 4th century BCE found at the temple provides evidence for an older sanctuary. ${ }^{156}$ It is not known whether this old sanctuary was also dedicated to Hecate.

An annual festival of the key was celebrated as main festival of Hecate at Lagina. ${ }^{157}$ As Hecate was a divine key-holder par excellence, and this aspect was especially emphasized during the Roman and Imperial periods, it is not surprising that a major festival of the key was celebrated in honour of Hecate at Lagina. Literary and epigraphic sources are silent about the details and origin of the festival. Apart from the Epikleidia, a festival of the key is not attested by written and iconographic sources for other Greek deities. As mentioned, IG II ${ }^{2} 4841$ (lines 9-10) records that Archeleos carried the key of Hera. This inscription does not tell us whether the key of Hera was carried in a procession that was part of a festival of the key. I.Smyrna 753 (lines 24-26) refers to a temple key carried in a procession that was part of a ritual begging. Presumably, the key was carried in these processions as an insignia of the temple without playing a central role. The key played an important role in the main festival celebrated at Lagina. The key-bearer of Hecate at Lagina seems to have had the most important task at this festival of the key. 

and Stratonikeia provide evidence for the festival of the key of Hecate at Lagina. ${ }^{158}$ The epigraphic sources are silent concerning the beginning of the festival of the key at Lagina. As not all inscriptions providing evidence for key-holders of Hecate at Lagina can be dated, the beginning and the end of the office of kleidophoros at Lagina cannot be determined with certainty. From the epigraphic sources, we do not know whether the office of key-bearer existed from the beginning of the festival of the key. We cannot exclude that the priest or priestess of Hecate at Lagina carried the key in the processions, and the office of key-bearer was established later. The beginning of the festival of the key may date to the 2nd century BCE when the sanctuary of Hecate at Lagina was founded. I.Stratonikeia 1048 (lines 2-7) dates to the Hellenistic period and is one of the earliest epigraphic sources on kleidophoroi and kleidos pompe of Hecate at Lagina. Most inscriptions providing evidence for kleidophoroi of Hecate at Lagina date to the Imperial period. commemorating the key-holders of Hecate at Lagina. The construction of a Christian chapel next to the altar in the sanctuary of Hecate at Lagina in $325 \mathrm{CE}$ may suggest that the shrine was not anymore under pagan control or only partially, and the festival of the key was presumably not celebrated as a main festival of the city. The sanctuary of Hecate at Lagina was abandoned after an earthquake in 365 CE. ${ }^{159}$

Honorary inscriptions dating to the Imperial period dedicated by the boule, the demos, and the gerusia honour priests, priestesses, and kleidophoroi of Hecate. ${ }^{160}$ The hiereus and honorary inscriptions identify women and men who held offices of priest, high priestess, priestess, and kleidophoros. I.Stratonikeia 237 (lines 6-7), 254 (line 2), and 236

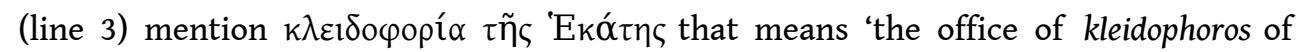
Hecate'. According to Laumonier, the office of priest was the highest office within the priestly hierarchy of the sanctuary of Hecate at Lagina, and the office of kleidophoros was prestigious and closely linked to the office of the priest. ${ }^{161}$ Some priestesses of Hecate at Lagina emphasize explicitly that they had the office of kleidophoros. The emphasis of the office of kleidophoros indicates that the office of kleidophoros of Hecate at Lagina had a high cultic status. This was apparently a prestigious office one had as a young girl before becoming a priestess, suggesting that the office of priest had a higher standing than that of the key-bearer. Some of the honorary inscriptions honour priestesses of Hecate as the daughters of the polis (Өuүó $\tau \eta \rho ~ \pi o ́ \lambda \varepsilon \omega \varsigma) .{ }^{162}$ The key-bearers were not honoured as the daughters of the polis. The hiereus and honorary inscriptions represent the priests and priestesses of Hecate at Lagina as benefactors of the city who financed festivals and made significant donations. These festivals and donations were a costly matter and only affordable for the wealthy families of the city who owned significant material resources. As Laumonier illustrates, the leading families from Lagina and Panamara occupied for several generations the cultic offices of major cults in both cities. ${ }^{163}$

The festival of the key was called kleidos agoge ${ }^{164}{ }^{16 l e i d a g o g e},{ }^{165}$ kleidagogia, ${ }^{166}$ and kleidos pompe. ${ }^{167}$ I will use the name 'kleidagogia' as a general term for the festival of the key of Hecate at Lagina. The inscriptions make allusions that the kleidagogia lasted several

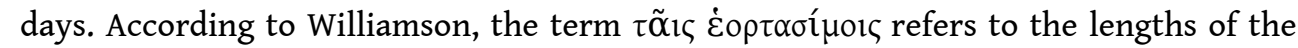
festival and means 'festival days'. ${ }^{168}$ This term means 'festivals' as well as 'festival days'. It can refer to several festivals or to a festival that lasted several days. I.Stratonikeia 685

Mythos, 13 | 2019 


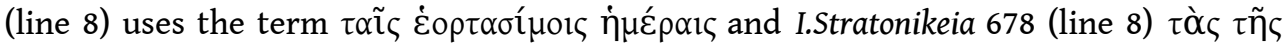
$\dot{\varepsilon} \circ \rho \tau \tilde{\eta} \varsigma \dot{\eta} \mu \varepsilon \varepsilon_{\rho} \alpha \varsigma$ for 'festival days', and indicate that the kleidagogia lasted several days.

The festival was a highly costly matter. This also emphasizes the significance of the cult of Hecate for Lagina. Aubriet states that the festival of the key included banquets, sacred drama, agones, distribution of money, meat, and oil. ${ }^{169}$ The inscriptions give partially insight into the different parts of the festival of the key. I.Stratonikeia 701 (lines 8-9) reveals that the priests of Hecate - Tiberius Claudius Aristeas Menandros and his wife Aelia Glykinna - were gymnasiarchs for two days during the procession of the key. ${ }^{170}$ I.Stratonikeia 663 (lines 9-10) mentions panegyreis, which lasted several days.

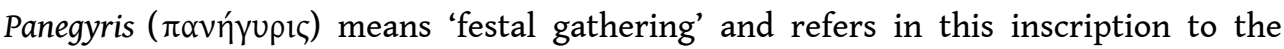
festival of the key. I.Stratonikeia 704 (line 8) speaks of banqueting ( $\dot{\varepsilon} \sigma \tau 1 \alpha$ ó $\sigma \varsigma$ - hestiasas), which also lasted several days. These inscriptions indicate that the kleidagogia lasted several days and included banquets. I.Stratonikeia 1048 (lines 4-6) mentions that the kleidophoros of Hecate attended the penteteric festival ( $\kappa \alpha \tau \grave{\alpha} \pi \varepsilon v \tau \alpha \varepsilon \tau \eta \rho i ́ \delta \alpha$ ) and conducted the kleidos pompe. The term penteteric suggests that the festival was celebrated penteterically. As the priests and the kleidophoroi of Hecate were appointed for a term, the kleidophoroi were presumably involved in festivals, which were celebrated annually and penteterically and included kleidos pompe. This means that the key was escorted at various festivals of Hecate, and presumably also at those of Zeus.

The highlight of the festival was the procession of the key called kleidos pompe ( $\kappa \lambda \varepsilon i \delta$ ò $\varsigma$ $\pi \circ \mu \pi \tilde{n}) \cdot{ }^{171}$ The temple key was carried in a procession from Straonikeia to Lagina and the kleidophoros may have solemnly unlocked the temple door of Hecate at Lagina. The epigraphic material does not mention the type of the key that was carried. The key carried in the processions was a symbolic key of Hecate or a key of the temple of Hecate at Lagina (I.Stratonikeia 1048, lines 2-6). Hatzfeld referred to I.Stratonikeia $669^{172}$ (line 6) and has suggested that the unlocking the temple door at Lagina was probably not a daily task and the kleidophoros unlocked the temple door at an annual festival of Hecate at Lagina. ${ }^{173}$ The inscriptions illustrate that the key was not only carried at one festival but at various festivals celebrated in honour of Hecate and Zeus. This means that the temple door was not only unlocked once a year. There is also no epigraphic evidence that the temple was only opened at festivals.

Apart from the stages of the festival of the key, the question arises whether it was a local festival. An inscription from Cos dating to the 1st century BCE records that boys attended the contests at the Hekateion in Stratonikeia (Iscr. di Cos EV 203, lines 9-11, 15-16). The same inscription also mentions that boys from Isthmus attended the contests (Iscr. di Cos EV 203, lines 9-11). ${ }^{174}$ The festival mentioned in Iscr. di Cos EV 203 refers to a major festival of Hecate at Lagina that was either celebrated annually or penteterically. As the major festival of Hecate at Lagina was the kleidagogia, the festival mentioned in the inscription from Cos may refer to this festival. This would mean that the kleidagogia was not a local festival.

63 The question arises whether the cult of Hecate at Lagina was a mystery cult and the key symbolised the key of the gates to Hades. This is also a question that will give a closer look on the features of the cult of Hecate at Lagina. Epigraphic and literary sources on the mysteries of Hecate are generally sparse. Apollonius Rhodius ( $3^{\text {rd }}$ century BCE) mentions in Argonautica 4.1020 that "the rites of the maiden that wanders by night, the

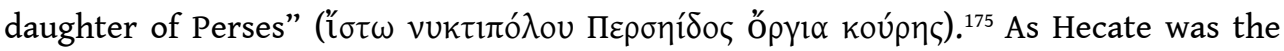
daughter of Perses (Homeric Hymn to Demeter 24), the orgia mentioned here refers to 
Hecate. Pausanias (2.30.2) tells us that the telete was performed in honour of Hecate on Aegina. Bremmer considers the telete ( $\tau \varepsilon \lambda \varepsilon \tau \eta \dot{)})$ of Hecate performed on Aegina as mysteries. ${ }^{176}$ Pausanias (2.30.2) says that the telete of Hecate on Aegina was established by Orpheus, who is linked to mysteries and to the underworld. ${ }^{177}$ Origen of Alexandria mentions in Contra Celsum 6.22 the initiation into the mysteries of Hecate on Aegina, and uses the term $\mu$ voupévorc. ${ }^{178}$ Dowden points out that the term telete means rite, but it was also used for ceremonies at Eleusis ${ }^{179}$ These ceremonies were presumably the first stage of the Eleusinian Mysteries. ${ }^{180}$ During the Hellenistic and following periods, the term telete was not exclusively used for the Eleusinian Mysteries and for mysteries in general, but also for different rituals. ${ }^{181}$ In this context, telete performed in honour of Hecate during the Imperial period may refer to different rituals.

Some inscriptions on the cult of Hecate from the territory of Stratonikeia, which were dedicated from the 2nd century CE onwards, use specific terms linked to the mysteries: orgiaphant and mystagogue. Schuddeboom believes that Myonides, who was a priest of Hera and honoured in I.Stratonikeia 541 (2nd century CE), was an orgiophant at the sanctuary of Hecate in Lagina. ${ }^{182}$ An orgiophant (ópүlopóvtnৎ) was a cultic official who revealed the sacred objects at the mysteries. ${ }^{183}$ Orgiophants are mentioned in connection with the orgia of Dionysus. ${ }^{184}$ I.Stratonikeia 674 (lines 9-10), 675 (line 5), and 310 (line 49) mentions the office of mystagogue. ${ }^{185}$ The mystagogue acted as epimelete and guided the initiates. I.Stratonikeia 310 (line 34) indicates that Marcus Sempronius Aruncius Theodotos and his sister Sempronia Aruncia Arriane, who were priests of Hera, Zeus, and Hecate at Panamara, completed the mysteries, which may be those of Hecate. ${ }^{186} \mathrm{We}$ learn from I.Stratonikeia 14 (lines 3-4) that Sosandros, the son of Diomedes, proposed that the mysteries should be celebrated after the death of the priest. The mysteries mentioned here refer presumably to those of Zeus and Hecate. ${ }^{187}$ Sosandros is also mentioned in I.Stratonikeia 1101 that concerns the cult of Zeus and Hecate. The terms orgiophant or mystagogue used in the inscriptions mentioned in this paper do not provide evidence for mysteries in classical sense, e.g. the Eleusinian Mysteries, which promised a better afterlife. The mysteries performed during the Hellenistic and later periods did not necessarily promise a better afterlife, as the meaning of mysteries changed during these periods. The features of the mysteries of Hecate at Lagina are not known. Our knowledge on the mysteries of Hecate in other cities is also limited.

As most inscriptions on Hecate from Lagina, Panamara, and Stratonikeia date to the Imperial period, we should reconsider the meaning of the 'mysteries' during this period. The use of the term mustêria during the Imperial period varies from rituals associated with initiations, like the Eleusinian Mysteries, and the experience of divinity. ${ }^{188}$ The mysteries performed in Asia Minor during the Imperial period differ in many respects from those performed in earlier periods. ${ }^{189}$ The classical mysteries were open to all people regardless of their gender and social background, whereas those performed in Asia Minor during the Imperial period were presumably restricted to the members of wealthy families. ${ }^{190}$ Cultic officials of different cults in the territory of Stratonikeia attested by epigraphic sources were also members of wealthy families. Mysteries performed by these cultic officials do not necessarily imply their restriction to rich people.

66 According to Zografou, Hecate was not worshipped as a chthonian goddess at Lagina and the key was a mystic key that cannot be identified with the key of the gates to the underworld. ${ }^{191}$ As Scullion points out, the term 'chthonian' is problematic. ${ }^{192}$ The term 
'chthonian' is used in associated with deities who are linked to the underworld or to agricultural fertility. ${ }^{193}$ As the epigraphic and iconographic sources from the territory of Stratonikeia do not indicate whether Hecate was worshipped as a goddess of agricultural fertility or as a goddess of the souls, it is misleading to use the term chthonian for the cult of Hecate at Lagina. Zografou has suggested that the key was probably the temple key and the temple door was opened ceremonially to the worshippers. ${ }^{194}$ The ceremonial opening of the temple door revealed the presence of Hecate and allowed the passage that favoured mysteries and initiation. ${ }^{195}$ The epigraphic sources do not indicate that the ceremonial opening of the temple door was linked to mysteries and initiation. Hecate is depicted on coins from Stratonikeia and on the frieze of her temple at Lagina with a torch and a bowl in the hand. Kraus states that the bowl and torches were cathartic. ${ }^{196}$ The bowl in the hand of Hecate does not refer to libation performed by the goddess, but by worshippers who performed it in honour of the goddess. ${ }^{197}$ Torches are linked to processions, festivals, mysteries, funerals, and wedding. We do not know in which context Hecate was represented with a torch in the hand.

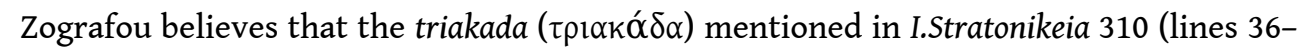
37) refers to a festival of Hecate that included banquets given in honour of the dead. ${ }^{198}$ The festival triakada of Hecate emphasizes her link to the underworld. ${ }^{199}$ Rituals of Hecate performed at Lagina may have promised a better afterlife or enhanced the bond with the goddess. The inscriptions from Lagina, Panamara, and Stratonikeia do not give the impression that Hecate was worshipped for a better afterlife.

Johnston refers to some scholars ${ }^{200}$ and states that the key carried at Lagina was a symbolic key that represented Hecate herself. ${ }^{201}$ Kraus argues convincingly that this key cannot be a symbolic key of Hecate and points out that Hecate was not depicted on coins and reliefs with a key and did not have epithets referring to her as a divine kleidouchos. ${ }^{202}$ The iconographic material from the sanctuary of Hecate at Lagina and the coins from Stratonikeia do not depict Hecate or cultic officials with a key. According to Nilsson, the kleidophoros carried the "heiligen Schlüssel" that means the 'sacred key'. ${ }^{203}$ The term 'sacred key' is also used in IG II $^{2} 4841$ (lines 9-10) and in The Trojan Women 256. Sacred keys were symbolic keys only used at rituals or escorted in processions. The symbolic key represented presumably the temple of Hecate that gave access to the presence of the goddess. The key carried at the various festival in Lagina was not an ordinary key used for unlocking the temple door at different occasions. This symbolic key was probably made of precious metal, had a special shape, and was larger than ordinary keys in order to highlight its sacral significance.

The key-bearer is referred to as $\kappa \lambda \varepsilon 1 \delta$

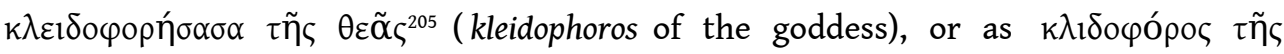

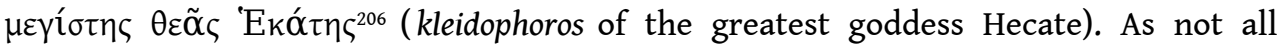
inscriptions are well preserved, only the names of one part of the kleidophoroi of Hecate at Lagina are known: Demostrate Apphion (I.Stratonikeia 17, lines 22-23), Ailia Tryphaina Drakontis (I.Stratonikeia 237, lines 6-7), Tatia (I.Stratonikeia 542, line 3), Flavia (I.Stratonikeia 663, line 17), Flavia Leontis (I.Stratonikeia 664, lines 6-7), and the wife of Demetrios Damylas Hierokometes (I.Stratonikeia 254, line 2). Several inscriptions reveal that the kleidophoros was an unmarried daughter of the priest of Hecate. ${ }^{207}$ The kleidophoroi were presumably very young, as girls were married at the age of 14 or a little bit later. I.Stratonikeia 254 (line 2) mentions that the priestess of Hecate was a high 
priestess and kleidophoros of the goddess. The priestess was a kleidophoros as a young girl, and later a priestess. We learn from I.Stratonikeia 542 (line 3) that Tatia, the wife of the priest of Hecate at Lagina, was a priestess and kleidophoros of Hecate. Tatia was first a kleidophoros and later a priestess of Hecate. ${ }^{208}$ I.Stratonikeia 17 (lines 23-24) provides another example for a priestess of Hecate at Lagina who had the office of kleidophoros as a young girl. Demostrate Apphion held the office of priest of Hecate at Lagina together with her husband, and her daughter was the kleidophoros (I.Stratonikeia 17, lines 23-24). I.Stratonikeia 683 reveals that Dionysios stood for the office of priest of Hecate and his daughter, Epainetis, for that of kleidophoros. Several inscriptions provide evidence to indicate that the kleidophoroi were the daughters of the priests of Hecate. ${ }^{209}$ I.Stratonikeia 17 and 2547 also illustrate that the members of a family through generations were priests and kleidophoroi of Hecate.

As the priest and the kleidophoros were selected for annual term and were members of leading families of the city, the number of proper candidates for the offices of priest and kleidophoros was not very high. We can assume that not all candidates for the office of priest had a daughter or a daughter of the proper age for the office of kleidophoros. In such cases, the daughter of another family was selected for the office of kleidophoros. I.Stratonikeia 676 reveals that Dionysios Epaphras Thrason and his wife Sescennia Polla were priests of Hecate. The kleidophoros was Sempronia Aristonike, who was not the daughter of the couple (I.Stratonikeia 676, lines 6-7). ${ }^{210}$ I.Stratonikeia 695 records that Lucius Rutilius Epainetos and Sempronia Apphion Artemisia had the office of priest, and Aurelia Melitine, the daughter of Menippos, was the kleidophoros.

Diehl and Cousin state that the priests of Hecate were selected for annual term and only once in their life. ${ }^{211}$ I.Stratonikeia 237 (lines 5-6) is the only inscription that mentions that a priestess, Ailia Tryphaina Drakontis, was a priestess of Hecate for the second

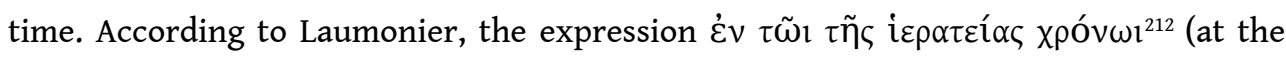
time of the priesthood) refers to annual priesthood. ${ }^{213}$ I.Stratonikeia 530 (lines 9-10) mentions that the priest and the priestess of Hecate fulfilled their duties for the entire year. I.Stratonikeia 1101 (line 15) dating to the 2nd century CE also says that the priest of Hecate at Lagina was appointed for an annual term.

Tiberius Flavius Sabianus Diomedes Menippos Hierokometes was a priest of Hecate at Lagina, and his daughter, Leontis, was the kleidophoros (I.Stratonikeia 663, lines 5-6). Before this office, he was a priest of Zeus at Panamara. Several members of the family of Flavii were priests of major cults at Panamara and Lagina. ${ }^{214}$ I.Stratonikeia 227 mentions the cultic offices of Hierokles and those of his wife and daughter. Hierokles held different political offices and made significant donations as benefactor of the city. He was honoured as a 'son of the polis' and his wife as a 'daughter of the polis'. Hierokles' son, Thrason Leon, was a high priest when he was 10 years old (I.Stratonikeia 667). He was a priest of Zeus Panamaros at the age of 16 , and a priest of Zeus Chryaorieos Propator when he was 20 years old. His wife, Apphia, was a priestess and his daughter, Ammia Apphia, was a kleidophoros of Hecate (I.Stratonikeia 667, lines 1112). Thraon Leon donated 10,000 denarii for the funding of corn (I.Stratonikeia line 9). Such an important donation shows the significant economic resources these families owned. I.Stratonikeia 227 and 667 illustrate that the families of kleidophoroi of Hecate at Lagina belonged to the wealthy families and occupied for generations high-ranking cultic and political offices. 


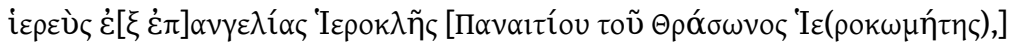

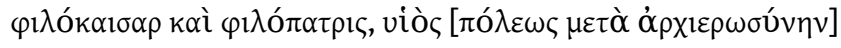

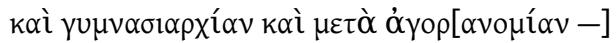

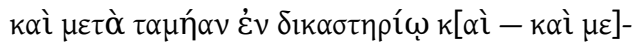

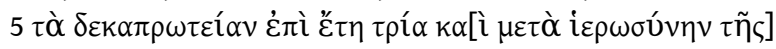

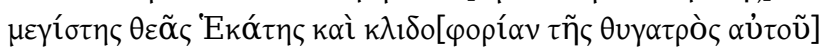

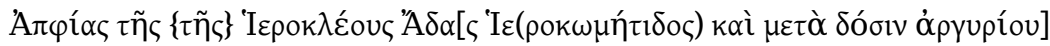

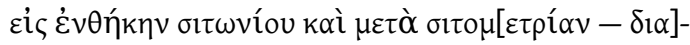

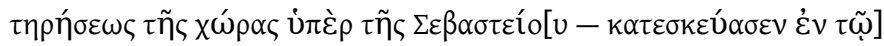

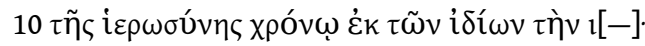

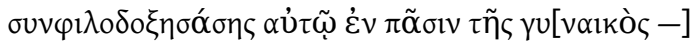

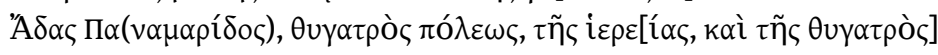

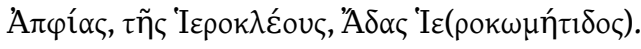

I.Stratonikeia 227

The priest, in accordance with his commitment, was Hierokles, the son of Panaitios

Thrason, from Hierokome, who was

philokaisar and philopatris, a son of the polis, after having been a high priest

and gymnasiarch and agoranomos

after having been treasurer of the court of justice

5 and after dekaprotos for three years and after the priesthood of

the greatest goddess Hecate and the office of kleidophoros of her daughter

Apphia Ada, the daughter of Hirokleos, from Hierokome, and after giving money

for the funding of corn and after the measurement of corn -

to keep the space for the Sebasteion - during his

10 priesthood, he constructed on his own expense the...

he contributed in all ways under [the priesthood] of his wife

Ada from Panamara, the daughter of polis, and his daughter

Apphia Ada, the daughter of Hierokleos from Hierokome.

\section{Conclusion}

The office of key-holder attested by epigraphic sources is a phenomenon that is mainly restricted to the Hellenistic, Roman, and Imperial periods, to a few cities, and cults. It seems likely that the office of key-holder also existed at many sanctuaries without being recorded in inscriptions. At most sanctuaries, the priests were probably at the same time the key-holders with no separate office of key-holder. If the office of keyholder existed in earlier periods, it had probably a low-ranking status and was not worth to be mentioned in inscriptions. This is likely at Olympia, where the key-holders of the sanctuary of Zeus were listed alongside low-rank officials. Some cultic offices were introduced in later periods, and some existing offices were only significant during a certain period. This may be the reason why the epigraphic sources dating to the Classical and to the early Hellenistic periods do not mention key-holders. Despite not having the same standing as the priest, the key-holders of some sanctuaries, such as those of Asclepius at Athens or of Hecate at Lagina, had a high-ranking cultic status and were from wealthy families who held high-ranking cultic and political offices over generations.

The office of kleidouchos of Asclepius and the Egyptian deities at Athens existed until the 3rd /4th centuries CE. The office of kleidouchos of Asclepius at Athens is attested by epigraphic sources for more than 300 years. The office of kleidophoros at Lagina existed at least until the first half of the 4th century $\mathrm{CE}$ and is also attested by epigraphic evidence for more than 300 years. With the so-called Theodosian Codex, which came 
into force in $439 \mathrm{CE}$, the pagan cult practices were forbidden (Theodosian Codex XVI.1.2). Several pagan sanctuaries were already closed under the Christian rules in the 4th century CE. The epigraphic record of key-holders of Greek temples also ends in this period.

\section{BIBLIOGRAPHY}

ACKERMAN 2013: D. Ackerman, «Les prêtrises mixtes: genre, religion et société», in M. Horster, A. Klöckner (eds.) Cities and Priests: Cult Personnel in Asia Minor and the Aegean Islands from the Hellenistic to the Imperial Period, Berlin 2013, 7-39.

ALESHIRE 1989: S.B. Aleshire, The Athenian Asklepieion: The People, Their Dedications, and the Inventories, Amsterdam 1989.

ATHANASSAKIS 2013: A.N. Athanassakis, B.M. Wolkow, The Orphic Hymns, Baltimore 2013.

AUBRIET 2012: D. Aubriet, «La cité de Stratonicée de Carie et ses bienfaiteurs: à propos de quelques titres honorifiques à l'époque impériale», in J.-C. Couvenhes (ed.), L'hellénisme, d'une rive à l'autre de la Méditerranée: Mélanges offerts à André Laronde, Paris 2012, 491-510.

BARTONĚK 2003: A. Bartoněk, Handbuch des mykenischen Griechisch, Heidelberg 2003.

BAUMBACH 2004: J.D. Baumbach, The Significance of Votive Offerings in Selected Hera Sanctuaries in the Peloponnese, Ionia and Western Greece, Oxford 2004.

BELAYCHE 2016: N. Belayche, «Les hiérophantes marqueurs des «mystères»? Le cas de l'Artémis éphésienne», in N. Belayche, F. Massa (eds.), Les «mystères»: questionner une catégorie, Mètis NS 14 (2016), 49-74.

BELAYCHE 2017: N. Belayche, «Nomen ostendit (Macrobe), Rites et images, les supports des noms de Janus», in N. Belayche, Y. Lehmann (eds.), Religions de Rome. Dans le sillage des travaux de Robert Schilling, Turnhout 2017, 67-83.

BELAYCHE, MASSA 2016: N. Belayche, F. Massa, «Quelques balises introductives: lexique et historiographie», in N. Belayche, F. Massa, (eds.), Les «mystères»: questionner une catégorie, Mètis NS 14 (2016), 7-19.

BETZ 1986: H.D. Betz, The Greek Magical Papyri in Translation, Chicago 1986.

BIELMAN SÁNCHEZ 2006: A. Bielman Sánchez, «Bilder (fast) ohne Worte: Die griechischen Grabstelen für Priesterinnen», in S. Schroer (ed), Images and Gender: Contributions to the Hermeneutics of Reading Ancient Art, Orbis Biblicus et Orientalis 220, Fribourg - Göttingen 2006, 351-378.

BÖTTICHER 1859: C. Bötticher, Der Omphalos des Zeus zu Delphi, Zum Winckelmannsfest der archäologischen Gesellschaft zu Berlin, vol. 19, Berlin 1859.

BREMMER 2013:J.N. Bremmer, «The Birth of the Personified Seasons (Horai) in Archaic and Classical Greece'», in Th. Greub (ed.), Das Bild der Jahreszeiten im Wandel der Kulturen und Zeiten, Munich 2013, 161-178.

BREMMER 2014: J.N. Bremmer, Initiation into the Mysteries of the Ancient World, Berlin - Boston 2014. 
BREMMER 2016: J.N. Bremmer, «Imperial Mysteries», in N. Belayche, F. Massa (eds.), Les «mystères»: questionner une catégorie, Mètis NS 14 (2016), 21-34.

BRUNEAU 1970: P. Bruneau, Recherches sur les cultes de Délos, Paris 1970.

BURKERT 2011a: W. Burkert, «The Meaning and Function of the Temple in Classical Greece», in E. Krummen (ed.), Kleine Schriften VI, Mythica, Ritualia, Religiosa 3: Kulte und Feste, Göttingen 2011, 2747.

BURKERT 2011b: W. Burkert, Griechische Religion der archaischen und klassischen Epoche, Stuttgart 2011.

CONNELLY 2007: J.B. Connelly, Portrait of a Priestess: Women and Ritual in Ancient Greece, Princeton 2007.

CORBETT 1970: P.E. Corbett, «Greek Temples and Greek Worshippers: The Literary and Archaeological Evidence», Bulletin of the Institute of Classical Studies at the University of London 17 (1970), 149-158.

DAREMBERG, SAGLIO 1873: C.V. Daremberg, E. Saglio, Dictionnaire des Antiquités grecques et romaines, vol. 3, Paris 1873.

DEBORD 1982: P. Debord, Aspects sociaux et économiques de la vie religieuse dans l'Anatolie grécoromaine, Leiden 1982.

DIEHL, CousIN 1887: C. Diehl, G. Cousin, «Inscriptions de Lagina», Bulletin de correspondance hellénique 11 (1887), 5-39.

DIELS 1914: H. Diels, Antike Technik, Leipzig - Berlin 1914.

DIGNAS 2010: B. Dignas, «A Day in the Life of a Greek Sanctuary», in D. Ogden (ed.), A Companion to Greek Religion, Malden - Oxford 2010, 163-177.

DILLON 2002: M. Dillon, Girls and Women in Classical Greek Religion, London 2002.

DOWDEN 1980: K. Dowden, «Grades in the Eleusinian Mysteries», Revue de l'histoire des religions 197 (1980), 409-427.

DUNAND 1973: F. Dunand, Le culte d'Isis dans le bassin oriental de la Méditerranée, vol. 26.3, Leiden 1973.

EISLER 1910: R. Eisler, Weltmantel und Himmelszelt, vol. 2, Munich 1910.

FARAONE 1997: C.A. Faraone. «Hymn to Selene-Hecate-Artemis from a Greek Magical Handbook (PGM IV 2714-83)», in M. Kiley (ed.) Prayer from Alexander to Constantine: A Critical Anthology, New York 1997, 195-199.

FOUCART 1885: P.-F. Foucart, «Inscriptions de Béotie», Bulletin de correspondance hellénique 9 (1885), 403-433.

FRAZER 1929: J.G. Frazer, Publii Ovidii Nasonis Fastorum Libri Sex, The Fasti of Ovid, London 1929.

GRAF 2015: F. Graf, Roman Festivals in the Greek East: From the Early Empire to the Middle Byzantine Era, Cambridge 2015

GREEN 2007: C.M.C. Green, Roman Religion and the Cult of Diana at Aricia, Cambridge 2007.

GUIDONI 1982: G.G. Guidoni, «Un bronzetto di Hekate proveniente da Classe. Storia et raffigurazioni delle divinità in epoca romana », Felix Ravenna 119-120 (1982), 33-55. 
HATZFELD 1920: J. Hatzfeld, «Inscriptions de Lagina en Carie», Bulletin de correspondance hellénique 44 (1920), 70-100.

HERDA 2011: A. Herda, «How to run a state cult: The Organisation of the Cult of Apollo Delphinios in Miletos», in M. Haysom, J. Wallensten (eds.) Current Approaches to Religion in Ancient Greece (Papers Presented at a Symposium at the Swedish Institute at Athens, 17-19 April 2008), Stockholm 2011, 57-93.

HEWITT 1909: J.W. Hewitt, «The Major Restriction on Access to Greek Temples», Transactions and Proceedings of the American Philological Association 40 (1909), 83-91.

HEYDEMANN 1874: H. Heydemann, Die antiken Marmor-Bildwerde in der sog. Stoa des Hadrian, dem Windthurm des Andronikus, dem Waerterhaeuschen auf der Akropolis und der Ephorie im Cultusministerium, Berlin 1874.

HOPFNER 1939: T. Hopfner, «Hekate-Selen-Artemis und Verwandte in den griechischen Zauberpapyri und auf den Fluchtafeln», in T. Klauser, A. Rücker (eds.), Pisciculi: Studien zur Religion und Kultur des Altertums, Franz Joseph Dölger zum 60. Geburtstage, Münster 1939, 125-145.

HотZ 2005: S. Hotz, Rituale im öffentlichen Diskurs griechischer Poleis der Kaiserzeit, unpublished dissertation, University of Heidelberg 2005.

HUBBE 1959: R.O. Hubbe, «Decrees from the Precinct of Asklepios at Athens», Hesperia 28.3 (1959), 169-201.

IODICE 2006: M. Iodice, «Ka-ra-wi-po-ro: La "portatrice di chiavi” nei testi micenei di Pilo», Aevum 80 (2006), 13-22.

JACCOTTET 2016: A.-F. Jaccottet, «Les mystères dionysiaques», in N. Belayche, F. Massa (eds.), Les «mystères»: questionner une catégorie, Mètis NS 14 (2016), 76-94.

JOHNSTON 1990: S.I. Johnston, Hekate Soteira: A Study of Hekate's Role in the Chaldean Oracles and Related Literature, Atlanta, Georgia 1990.

JOHNSTON 1999: S.I. Johnston, Restless Dead: Encounters between the Living and the Dead in Ancient Greece, Berkeley, CA 1999.

KALTSAS, SHAPIRO 2008: N. Kaltsas, A. Shapiro (eds.), Worshiping Women: Ritual and Reality in Classical Athens, New York, N.Y. 2008.

KEARNS 1992: E. Kearns, «Between God and Man: Status and Functions of Heroes and their Sanctuaries», in A. Schachter (ed.), Le sanctuaire grec (Vandoeuvres - Genève, 20-25 août 1990, huit exposés suivis de discussions), Geneva 1992, 65-99.

KERN 1922: O. Kern, Orphicorum Fragmenta, Berlin 1922.

KINNEY 1994: D. Kinney, «The Iconography of the Ivory Diptych Nicomachorum-Symmachorum», Jahrbuch für Antike und Christentum 37 (1994), 64-96.

KIRFEL 1948: W. Kirfel, Die dreiköpfige Gottheit, Bonn 1948.

KLÖCKNER 2013: A. Klöckner, «Dienerinnen der Demeter? Zu einer Gruppe von Grabreliefs aus Smyrna», in M. Horster, A. Klöckner (eds.), Cities and Priests: Cult Personnel in Asia Minor and the Aegean Islands from the Hellenistic to the Imperial Period, Berlin 2013, 303-353.

KÖHLER 1905: W. Köhler, «Die Schlüssel des Petrus. Versuch einer religionsgeschichtlichen Erklärung von Matth. 16, 18.19», Archiv für Religionswissenschaft 8 (1905), 214-243.

KROLL 1899: W. Kroll (ed.) Procli Diadochi in Platonis Rem pvblicam commentarii, vol. II, Leipzig 1899. 
KOSMOPOULOU 2001: A. Kosmopoulou, «Working Women: Female Professionals on Classical Attic Gravestones», Annual of the British School of Athens 98 (2001), 281-319.

KRAUS 1960: T. Kraus, Hekate: Studien zu Wesen und Bild der Göttin in Kleinasien und Griechenland, Heidelberg 1960.

KRUG 1967: A. Krug, Binden in der griechischen Kunst: Untersuchungen zur Typologie (6. - 1. Jahrh. v. Chr.), unpublished dissertation, Johannes-Gutenberg-Universität Mainz 1967.

LABUfF 2015: J. LaBuff, Polis Expansion and Elite Power in Hellenistic Karia, Maryland 2015.

LAPATIN 2010: K. Lapatin, New Statues for Old Gods, in: J.N. Bremmer, A. Erskine (eds.), The Gods of Ancient Greece: Identities and Transformations, Edinburgh 2010, 126-151.

LAUMONIER 1937: A. Laumonier, A. «Recherches sur la chronologie des prêtres de Panamara», Bulletin de correspondance hellénique 61 (1937), 236-298.

LAUMONIER 1938: A. Laumonier, «Recherches sur la chronologie des prêtres de Lagina», Bulletin de correspondance hellénique 62 (1938), 167-179, 251-284.

LAUMONIER 1958: A. Laumonier, Les cultes indigènes en Carie, Paris 1958.

LECHAT 1891: H. Lechat, «Terres cuites de Corcyre», Bulletin de correspondance hellénique 15 (1891), $1-122$.

LEGRAND 1900: P.E. Legrand, «Inscriptions de Trézène», Bulletin de correspondance hellénique 24 (1900), 179-215.

MAIR, MAIR 1921: A.W. Mair, G.R. Mair, Callimachus, Hymns and Epigrams. Lycophron. Aratus, London 1921.

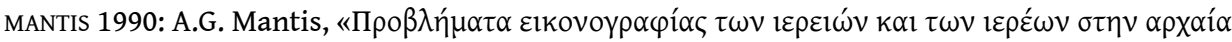

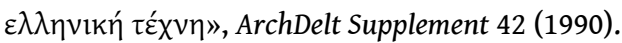

MAJERCIK 1989: R. Majercik, The Chaldean Oracles, Leiden 1989.

MÉNARD 2006: H. Ménard, «Un aspect de la custodia templorum: les aeditui», in A. Vigourt, X. Loriot, A. Bérenger-Badel, B. Klein (eds.), Pouvoir et religion dans le monde romaine, en hommage à Jean-Pierre Martin, Paris 2006, 231-243.

MORAND 2001: A.F. Morand, Études sur les hymnes orphiques, Leiden 2001.

MOTTE, PIRENNE-DELFORGE 1992: A. Motte, V. Pirenne-Delforge, «Le mot et les rites. Aperçu des significations de ǒpүı et de quelques dérivés», Kernos 5 (1992), 119-140.

MÜLLER 1839: K.O. Müller, Sexti Pompei Festi De verborum significatione quae supersunt cum Pauli Epitome, Leipzig 1839.

MURRAY 1924: A.T. Murray, Homer. The Iliad, London 1924.

NAKASSIS 2013: D. Nakassis, Individuals and Society in Mycenaean Pylos, Leiden 2013.

NERVEGNA 2014: S. Nervegna, «Performing Classics: The Tragic Canon in the Fourth Century and Beyond», in E. Csapo, H.R. Goette, J.R. Green, P. Wilson (eds.), Greek Theatre in the Fourth Century B.C., Berlin - Boston 2014, 157-188.

NEUBURGER 1919: A. Neuburger, Die Technik des Altertums, Leipzig 1919.

NILSSON 1906: M.P. Nilsson, Griechische Feste von religiöser Bedeutung mit Ausschluss der attischen, Leipzig 1906. 
NILSSON 1940: M.P. Nilsson, Greek Folk Religion, New York 1940.

NILSSON 1974: M.P. Nilsson, Geschichte der griechischen Religion: Die Hellenistische und römische Zeit, Munich 1974.

OLSEN 2014: B.A. Olsen, Women in the Mycenaean Greece: The Linear B Tablets from Pylos and Knossos, New York; Oxford 2014.

PFUHL, MÖBIUS 1977-79: E. Pfuhl, H. Möbius, Die ostgriechischen Grabreliefs, Mainz 1977-79.

PIÉRART 2000: M. Piérart, «Héros fondateurs. Héros civilisateurs. La rivalité entre Argos et Athènes vue par Pausanias», in V. Pirenne-Delforge, E. Suárez de la Torre (eds.), Héros et héroïne dans les mythes et les cultes grecs, Liège 2000, 409-434.

PETRIDOU 2015: G. Petridou, Divine Epiphany in Greek Literature and Culture, Oxford 2015.

PREISENDANZ 1928: K. Preisendanz, Papyri Graecae Magicae. Die griechischen Zauberpapyri, vol. I, Leipzig 1928.

PREISENDANZ 1931: K. Preisendanz Papyri Graecae Magicae. Die griechischen Zauberpapyri, vol. II, Leipzig 1931.

PODEMANN SøRENSEN 1989: J. Podemann Sørensen, Rethinking Religion: Studies in Hellenistic Process, Copenhagen 1989.

QUANTIN 2006: F. Quantin, «Artemis à Apollonia aux époques hellénistique et romaine», in Cabanes, P., Lamboley, J.-L. (eds.), L'Illyrie méridionale et l'Épire dans l'Antiquité, vol. IV (Actes du IV Colloque international de Grenoble, 10-12 octobre 2002), Paris 2006, 595-608.

QUASS 1993: F. Quaß, Die Honoratiorenschicht in den Städten des griechischen Ostens, Stuttgart 1993. REINACH 1900: T. Reinach, «Un nouveau proconsul d'Achaïe», Bulletin de correspondance hellénique 24 (1900), 324-328.

RHOMIOPOULOU, SCHMIDT-DOUNAS 2010: K. Rhomiopoulou, B. Schmidt-Dounas, Das Palmettengrab in Lefkadia, Mainz 2010.

ROBERTSON1983: N. Robertson, «Greek Ritual Begging in Aid of Women's Fertility and Childbirth», Transactions of the American Philological Association 113 (1983), 143-169.

ROUSSEL 1915-16 : P. Roussel, Les cultes égyptiens à Délos du IIIe au $1^{\text {er }}$ siècle av. J.C., Paris - Nancy 1915-16.

SARADI, ELIOPOULOS 2011: H.G. Saradi, D. Eliopoulos, «Late Paganism and Christianisation in Greece», in L. Lavan, M. Mulryan (eds.), The Archaeology of Late Antiquity 'Paganism', Leiden 2011, 263-308.

SCHILLING 1960: M.R. Schilling, «Janus. Le dieu introducteur. Le dieu des passages», Mélanges d'archéologie et d'histoire 72 (1960), 89-131.

SCHIPPOREIT 2013: S.T. Schipporeit, Kulte und Heiligtümer der Demeter und Kore in Ionien, Istanbul 2013.

SCHOBER 1933: A. Schober, Der Fries des Hekateions von Lagina, Vienna 1933.

SCHRÖDER 1986: H.O. Schröder, Publius Aelius Aristides: Heilige Berichte, Heidelberg 1986.

SCHUDDEвоOM 2009: F. Schuddeboom, Greek Religious Terminology: Telete \& Orgia: A Revised and Expanded English Edition of the Studies by Zijderveld and Van der Burg, Leiden 2009.

SCULLION 1994: S. Scullion, «Olympian and Chthonian», Classical Antiquity 13 (1994), 75-119. 
SEIFFERT 2006: A. Seiffert, Der sakrale Schutz von Grenzen im antiken Griechenland - Formen und Ikonographie, unpublished dissertation, Julius-Maximilians-Universität Würzburg 2006.

SEZGIN 2008: T. Sezgin, «Lagina ve Börükçü 2007 çalışmaları», Kazı Sonuçları Toplantısı 30.4 (2008), 245-248.

SFAMENI GASPARRO 1985: G. Sfameni Gasparro, Soteriology and Mystic Aspects in the Cult of Cybele and Attis, Leiden 1985.

SHELMERDINE 2017: C.W. Shelmerdine, «Exceptional Women: Female roles and power in the Linear

B Tablets», in M.L. Nosch, H.L. Enegren (eds.), Aegean Scripts (Procedings of the 14th International Colloquium on Mycenaean Studies Copenhagen, 2-5 September 2015), Rome 2017, 363-380.

SIRONEN 1997: E. Sironen, The Late Roman and Early Byzantine Inscriptions of Athens and Attica, Helsinki 1997.

TAPLIN 2007: O. Taplin, Pots \& Plays: Interactions between Tragedy and Greek Vase-painting of the Fourth Century B.C., Los Angeles 2007.

THOMPSON 2007: L.L. Thompson, «ISmyrna 735: Gods and the One God», in D.E. Aune, R.D. Young (eds.), Reading Religions in the Ancient World, Essays Presented to Robert McQueen Grant on his $90^{\text {th }}$ Birthday, Leiden 2007, 101-122.

TIRPAN, GIDER, BÜYÜKÖZER 2012: A.A. Tirpan, Z. Gider, A. Büyüközer, «The Temple of Hekate at Lagina», in T. Schulz (ed.), Dipteros und Pseudodipteros: Bauhistorische und archäologische Forschungen, Istanbul 2012, 181-202.

VENTRIS, CHADWICK 1956: M. Ventris, J. Chadwick, Documents in Mycenaean Greek, Cambridge 1956. VON RUDLOFF 1999: R. von Rudloff, Hekate in Ancient Greek Religion, Victoria, BC 1999.

WALTERS 1988: E.J. Walters, Attic Grave Reliefs That Represent Women in the Dress of Isis, Princeton, New Jersey 1988.

WEISS 2004: A. Weiss, Sklave der Stadt: Untersuchungen zur öffentlichen Sklaverei in den Städten des Römischen Reichs, Stuttgart 2004.

WERTH 2006: N. Werth, Hekate: Untersuchungen zur dreigestaltigen Göttin, Hamburg 2006.

WILHELM 1891: A. Wilhelm, «Inschriften aus Messene», Athenische Mitteilungen 16 (1891), 345-355. WILLIAMSON 2013: C.R. Williamson, «Civic Producers at Stratonikeia. The Priesthood of Hekate at Lagina and Zeus at Panamara», in M. Horster, A. Klöckner (eds.), Cities and Priests: Cult Personnel in Asia Minor and the Aegean Islands from the Hellenistic to the Imperial Period, Boston 2013, 209-246. zOGRAFOU 2010: A. Zografou, Chemins d'Hécate: Portes, routes, carrefours et autres figures de l'entredeux, Kernos Supplément 24, Liège 2010.

ZOUMBAKI 2001: S.B. Zoumbaki, Elis und Olympia in der Kaiserzeit: das Leben einer Gesellschaft zwischen Stadt und Heiligtum auf prosopographischer Grundlage, Athens 2001.

ZWIERLEIN-DIEHL 2007: E. Zwierlein-Diehl, Antike Gemmen und ihr Nachleben, Berlin - New York 2007.

\section{NOTES}

1. I would like to express my gratitude to Nicole Belayche, who read and commented on my paper. Her comments have contributed a lot to this paper. I am also very grateful to the 
anonymous reviewers for their very insightful and incisive comments. All translations are mine, unless otherwise indicated.

2. It refers to a city called Dotium located in Thessaly and holly to Demeter (Callim. Hymn to Demeter 24).

3. For the temple key and lockers, see DIELS 1914, 36-45; NEUBURGER 1919, 339.

4. Homer's Odyssey was probably composed around the 8th or 7th century BCE. For doors of houses and temples, see also DAREMBERG, SAGLIO 1873, 603-609.

5. A temple key dating to the 5th century BCE was found in the sanctuary of Zeus on Mount Lykaios in Arcadia (Athens, National Archaeological Museum Inv. 13223). According to PALAIOKRASSA, the key was probably used for a door of a building at this site $(2008,214)$. Several temple keys were found in the sanctuary of Olympia (Archaeological Museum of Olympia).

6. The metal bar - the so-called temple key - was inserted through a hole in the door, and the bolt, which kept the door closed, was pushed back.

7. For the Laconian lockers and keys, see DIELs 1914, 46-48.

8. For the restriction on access to Greek temples, see HEWITT 1909, 83-91; CORBETT 1970, 150sqq; BURKERT 2011a, 185.

9. MANTIS $1990,28-65$.

10. DILLON 2002, 80-82; CONNELLY 2007, 92-104; KALTSAS, SHAPIRO 2008, 194-195, 198-214, nos. 78, 80 91.

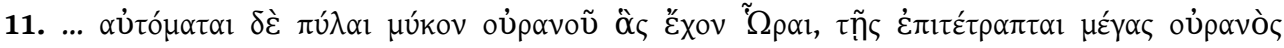

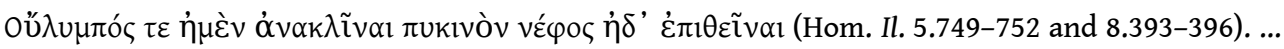
self-bidden groaned upon their hinges the gates of heaven, which the Hours had in their keeping, to whom are entrusted great heaven and Olympus, whether to throw open the thick cloud or shut it to (translation by MURRAY 1924).

12. Aurora was the goddess of the morning (Ov. Met. 3.156-157).

13. BREMMER 2013, 165.

14. BREMMER 2013, 166.

15. Orphic Hymns were composed in Asia Minor in the 3rd century BCE-3rd century CE (ATHANASSAKIS, WOLKOW 2013, X). The following deities were entitled in the Orphic Hymns as keyholders of the gates to Hades and of different aspects of life: Musaeus as key-holder of the world (Orphic Hymn to Musaeus 60); Hecate as key-holder of the cosmos (Orphic Hymn to Hecate, line 7), Prothyraea (Artemis) as key-holder of the nature (Orphic Hymn to Prothyraea 7-8); Proteus as keyholder of the chambers of the deep (Orphic Hymn Proteus 1-2); Plouton as key-holder of the earth (Orphic Hymn to Plouton 7-8) and Hades (Paus. 5.20.3); Eros as key-holder of heaven and earth (Orphic Hymn to Cupid 5-6); Daemon as key-holder of sorrow and delight (Orphic Hymn to Daemon 10).

16. Papyri Graecae Magicae (PGM) were composed in Egypt in the 2nd century BCE-5th century CE For PMG, see PREISENDANZ 1928; 1931; BETZ 1986. The following deities are named 'key-holder in PGM: The Egyptian god Anubis (PGM 4.235-245), Aiakos (PGM 4.1466), Hermes (PGM 4.2292), Persephone (PGM 4.1403), and Hecate (PGM 4.2836).

17. For Janus, see also SCHILLING 1960, 90-100; BELAYCHE 2017, 70sqq.

18. EISLER 1910, 440sq.

19. KRAUS $1960,19,50$.

20. KRAUS 1960, 19.

21. For inscriptions providing evidence for key-holders of Hecate at Lagina, see the subchapter 'Hecate as divine key-holder and her festival of the key'.

22. M. SCHMIDT, Hesychii Alexandrini lexicon, Jena 1867.

23. Varro Ling. 6.19

24. Cic. Nat. D. 2.66. 
25. Fest. s.v. Claudere.

26. See FRAZER 1929, 228.

27. See also Eur. Tro. 492-495.

28. Cic. Phil. 2.69.

29. Fest. 3. For more details, see MÜLLER 1839, 56; ZWIERLEIN-DIEHL 2007, 227.

30. PY Eb 338; PY Jn 829; PY Ep 704; PY Ed 714; PY Ed 317; PY Qa 1289; PY Qa 1330; PY Un 6; PY Un 443; PY Un 998; PY Vn 48. Iodice discussed in detail several Linear B tablets from Pylos that mention ka-ra-wi-po-ro $(2006,13-22)$. Hector Williams kindly informed me that these Linear B tablets date to $1200 \mathrm{BCE}$.

31. Mycenaean Greek.

32. For ka-ra-wi-po-ro, see also VENTRIS, CHADWICK 1956, 128; BARTONĚK 2003, 202, 373, 432; IODICE 2006, 16.

33. NAKASSIS 2013, 11.

34. NAKASSIS 2013, 130.

35. NAKASSIS 2013, 130.

36. SHELMERDINE 2017, 365.

37. IODICE 2006, 16; SHELMERDINE 2017, 364.

38. OLSEN $2014,140$.

39. See also SHELMERDINE 2017, 364-365.

40. See the inscriptions from Athens, Olympia, and Delos (fn. 71, 73, and 81).

41. I.Stratonikeia 532 (line 5), 539 (lines 7, 11), 542 (line 3), 663 (lines 5, 17), 664 (line 6), 667 (line 11), 674 (line 20), 678 (line 9), 683 (line 4), 690 (lines 7,8, 10), 702 (line 2), 705 (line 15), 707 (line 1), 708 (lines 1, 4), 709 (line 1), 711 (lines 2-3), 712 (line 1), 713 (line 1).

42. See fn. 29.

43. IG V,1 1390

44. IG II ${ }^{2} 4573$ (line 5); IG XI,4 1186 (line 4); Clem. Al. Strom. 1.24.

45. I.Stratonikeia 17 (line 22-23), 225 (line 7), 227 (line 6), 256 (line 2), 327 (line 4), 532 (line 6), 538 (line 3), 540 (line 2), 666 (line 3), 676 (line 6), 680 (line 4), 693 (line 8), 695 (line 11), 707 (line 9), 710 (line 3), 1028 (line 4), and IK Side I 17.

46. Troizen (IG IV 768, 3rd century BCE), Epidaurus (IG IV 2 ,1 297, 3rd century BCE), and Messene (IG V,1 1447, $191 \mathrm{BCE})$.

47. JÖAI 8 (1905) 168,4/5.3, line 7 (132/3 CE); IK Side I 17, face B, lines 1-2 (2nd-3rd c. CE). See the subchapter 'Hecate as divine key-holder and her festival of the key'.

48. QUANTIN 2006, 596sq, fig. 1-2. The statue depicts a woman whose arms and head are broken. She might have been depicted with a key in the hand.

49. See also Paus. 4.31.3.

50. Only a few books are mentioned here, which use the term 'key-bearer' for kleidouchos. Keybearer: DILLON 2001, 81; CONNELlY 2007, 95; DIGNAS 2010, 175. Schlüsselträger, KÖHLER 1905, 220; ThesCRA V 2005, 385. Porte-clef: PIÉRART 2000, 384.

51. Didymus Caecus, De trinitate 39.728.2; Joannes Chrysostomus, In duedecim apostolos 59.496.15; Joannes Damascenus, Homilia in transfigurationem domini 96.556 .35 . The three books are published in J.-P. MIGNE, Patrologiae cursus completes, Paris 1857-1866.

52. Hyg. Grom. De munit. castr. 55.

53. WEISS 2004, 142, fn. 157; MÉNARD 2006, 233.

54. MÉNARD 2006, 243.

55. MÉNARD 2006, 232-236.

56. MÉNARD 2006, 239.

57. LECHAT 1891, 32, no 12, fig. 4.

58. Nicole Belayche drew my attention to the Roman key-holders (aeditui) who were always men. 
59. MANTIS 1990, pl. $6 \mathrm{~b}$.

60. RHOMIOPOULOU, SCHMIDT-DOUNAS 2010, 75, pl. 9.

61. For woollen ribbons, see KRUG 1967, 37-41; ThesCRA V 2005, 400.

62. LIMC: Lexicon Iconographicum Mythologiae Classicae

63. For the description and further discussion, see CONNELLY 2007, 98-103.

64. TAPLIN 2007, 58, 150-154, 199; NERVEGNA 2014, 172-176. Taplin analysed more than 100 vases from South Italy, which illustrate the intersection between vase painting and dramatic scenes from the plays of Euripides, Aeschylus, and Sophocles (2007).

65. KOSMOPOULOU 2001, 282sqq.

66. BIELMAN SÁNCHEZ 2006, 358.

67. I.Smyrna 7-9, 15, 29, 81, 86, 103, 106, and 888. For these stelai, see PFUHL, MÖBIUS 1977-79, nos. 405-410, 529-531, 855, 872 .

68. ThesCRA III 2006, nos. 77, 78; KLÖCKNER 2013, 305-331; SCHIPPOREIT 2013, 196.

69. For the garments of priestesses of Isis, see WALTERS 1988.

70. According to CONNELLY, the base was a funerary altar $(2007,245)$. FOUCART believed that it was a statue base $(1885,406)$. Ivy is especially known for the cult of Dionysus and in sepulchral art. It was presumably a funerary altar, as the depiction of a temple key with a wreath is well attested for grave stelai.

71. Inscriptions from Athens on key-holders: Asclepius and Hygeia (IG II $^{2}$ 974, line 23; 975, lines 13-14; 1944, lines 16, 21, 31; 3704, lines 13-14; 3798, line 8; 3997, line 6; 4456, line 2; 4480, line 5); Egyptian deities (IG II ${ }^{2}$ 1950, line 15; 3564, line 2; 3644, line 2; SEG 42:157, lines 11-12); Artemis Agotera ( $I G \mathrm{II}^{2} 4573$, line 5); Hera (IG II ${ }^{2} 4841$, line 7). IG $\mathrm{II}^{2} 3728$ (line 6) is not complete and the name of the deity is not preserved. A single inscription is from Eleusis ( $I G \mathrm{II}^{2} 4823$, line 7). The name of the deity is not mentioned, but as the inscription was found at the sanctuary of Asclepius, it was apparently dedicated to the key-holder of Asclepius.

72. See fn 81.

73. The inscriptions from Delos were dedicated from 165 to 88 BCE: I.Delos 2037 (line 6), 2204 (line 3), 2210 (line 8), 2221 (line 9), 2222 (line 5), 2228 (lines 3, 8), 2232 (line 6), 2234 (line 19), 2248 (line 11), 2249 (line 7), 2364 (line 10), 2415 (lines 6-7), 2526 (line 4), 2527 (line 4), and 2601 (line 3). Keyholders are attested for the cults on Delos: Zeus Kynthos and Athena Kynthia (I.Delos 1891, line 2; 1892, line 3; 1893, line 2; 1894, line 3; 1895, line 4); Egyptian deities (I.Delos 2070, line 4; 2081 line 4; 2094, line 4; 2104, line 8; 2157, line 8; 2415, lines 6-7; 2157, line 8; 2221, line 9; 2222, line 5; 2228, lines 3, 8); 2248, line 11), and 2605 (line 34); Artemis, Apollo, and Leto (I.Delos 1443 (line B 1.1 163), 1444 (line A 46, B 3), 1830 (line 7), 1875 line 4; 1876); Apollo Neirion (I.Delos 1403, line 91); Agathe Tyche (I.Delos 1426, line 9); Aphrodite (I.Delos 2234, line 19; 2248, line 11).

74. See the subchapter 'Hecate as divine key-holder and her festival of the key'.

75. A relief dating to the $4^{\text {th }}$ century BCE depicts a bearded man and a key. The man represents a priest and the key is used as an insignia for his office of priest.

76. IG XII 4, 1, 71 mentions that four keys of thesauroi were shared by four cultic officials of Asclepius. The thesauroi refer to treasury houses or to stone boxes used for the collection of money.

77. The funerary inscription IGUR III 1245 from Rome ( $3^{\text {rd }}$ century CE) mentions Aeacus as keyholder of Hades.

78. For key-holders of Asclepius in Attica see fn. 71. Cos: IG XII 4,1,71 ( $2^{\text {nd }}$ c. BCE).

79. For the key-holders of the Egyptian deities in Attica (fn. 71) and on Delos (fn. 73).

80. Attica: IG II $^{2} 4841$, line 7 (361-378 CE).

81. Epigraphic sources on key-holders of Zeus at Olympia: IvO 61, lines 7 and 10 (36 BCE); IvO 62, line 10 (36-24 BCE); IvO 64, line 14 (28-24 BCE); IvO 65, line 17 (20-16 BCE); IvO 66, line 2 (50 BCE); 
IvO 69, line19 (5 CE). For inscriptions on key-holders of Zeus Kynthios and Athena Kynthia on Delos, see fn. 73.

82. See fn. 73.

83. Andania: IG V,1 1390, face A, line 91 (92 BCE).

84. Epigraphic sources on key-holders of Apollo on Delos, see fn. 73. Kolophon, Klaros: JÖAI 8 (1905) 168,4/5.3, line 7.

85. Epigraphic sources on key-holders of Artemis from Attica: $I G \mathrm{II}^{2} 4573$, line 5 ( $350 \mathrm{BCE}$ ). For Delos, see fn. 73.

86. For epigraphic sources on key-bearers of Artemis, Apollo, and Leto from Delos, see fn. 73.

87. For inscriptions of key-holders of Aphrodite on Delos, see fn. 73.

88. See the subchapter 'Hecate as divine key-holder and her festival of the key'.

89. IG $\mathrm{II}^{2} 4573$ (line 5) is the only inscription from Athens dating to $350 \mathrm{BCE}$.

90. IG V,1 1390 from Andania dates to 92/91 BCE. This inscription mentions that the priest and the cultic officials, who were not called 'key-holders' of a temple, had the keys of the thesauroi.

91. For the inscriptions, see fn. 71.

92. IG $\mathrm{II}^{2}$ 974, lines 23-24 (137 BCE); IG II ${ }^{2}$ 975, lines 12-14 (112-110 BCE).

93. IG II ${ }^{2} 3704$, lines 11-14 (225-235 CE).

94. ALESHIRE 1989, 89.

95. HUBBE 1959, 194.

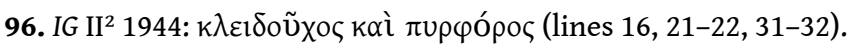

97. For the restoration of IG II ${ }^{2} 974$, see SEG 18:26 and HUBBE (1959, 188-189, 193, no 10).

98. HUBBE 1959, 193-194.

99. ALESHIRE 1989, 90.

100. SCHRÖDER 1986, 22, fn. 19.

101. The cult statues are referred to as deities (Liv. 38.43.5; Lucian, On Sacrifice 11; Pseudo Lucian, Lucius 41). For further discussions, see PETRIDOU 2015, 50sqq.

102. For the noble background, see also Arist. Rh. 2.15.

103. IG $\mathrm{II}^{2}$ 1950, line 15 ( 3 rd century CE); IG II ${ }^{2} 3564$, line 2 (1st/2nd century CE); IG $\mathrm{II}^{2} 3644$, lines 2-3 (2nd century CE); SEG 42:157, lines 11-12 (116-95 BCE).

104. DUNAND 1973, 161.

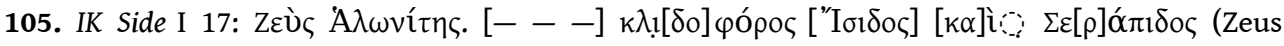
Alonites . [- - $]$ klidophoros of Isis and Serapis).

106. Alopeke and Phyla were Attic cities. Laodikea may refer to a city in Asia Minor.

107. Stolistes was a cultic official in charge of the clothing and cleaning of the cult statue.

108. DUNAND 1973, 161.

109. PODEMANN SøRENSEN $1989,78$.

110. ROUSSEL 1915-16, 268; HATZFELD 1920, 83.

111. PODEMANN SøRENSEN 1989, 78.

112. ZOUMBAKI states that the epispondorchestai were slaves who performed dances at cultic rituals (2001, 76, 129-130).

113. ZOUMBAKI $2001,127$.

114. zOUMBAKI 2001, 127.

115. For epispondorchestes, see zOUMBAKI 2001,130sq.

116. THOMPSON 2007, 105.

117. ROBERTSON 1983, 143sq; BURKERT 2011b, 160.

118. BURKERT 1977, 160-161; DEBORD 1982, 196; ROBERTSON 1983, 144sqq.

119. ROBERTSON 1983, 144.

120. BURKERT 2011b, 160.

121. SIRONEN 1997, 92. 
122. For details, see also HEYDEMANN 1874, 140sqq, no. 379; KINNEY 1994, 87-91; SIRONEN 1997, 92-94; SCHUDDEBOOM 2009, 220, no. 48; SARADI, ELIOPOULOS 2011, 289sq. The altar is preserved at the National Museum at Athens (Inv. 1746). The altar is $38 \mathrm{~cm}$ high, $34 \mathrm{~cm}$ wide, and $37 \mathrm{~cm}$ deep (SIRONEN 1997, 92).

123. Sfameni GASPARRO $1985,116$.

124. A taurobolic altar from Rome dating to 377 CE was also dedicated to Rhea and Attis (IGUR I 128).

125. SARADI, ELIOPOULOS 2011, 286.

126. SARADI, ELIOPOULOS 2011, 286. For taurobolium, see also SFAMENI GASPARRO 1985, 107-118.

127. SIRONEN 1997, 94. See also REINACH 1900, 325.

128. Athena says in Aesch. Eum. 825-830 that she alone of the gods knows, where the keys of the house of the thunderbolt of Zeus are. Athena was, however, not the key-holder of this house.

129. ВАUMBACH 2004, 81.

130. BAUMBACH 2004, 81.

131. WILHELM 1891, 354.

132. LEGRAND 1900, 202.

133. KEARNS 1992, 82, fn. 19.

134. KEARNS 1992, 82, fn. 19.

135. NILSSON 1940, 80.

136. WILHELM 1891, 352.

137. Cf. LSCG 64

138. WILHELM 1891, 354.

139. Hes. Theog. 425-426. See also the Orphic fr. 316 (KERN 1922, 324; MAJERCIK 1989, 213, fr. 197; JOHNSTON 1990, 39-40). JOHNSTON analysed literary sources on Hecate as kleidouchos (1989, 39-48).

140. Plut. De def. or. 13 and De fac. 29. For the comparison of Hecate with Anubis, see Plut. De Is. et Os. 44.

141. JOHNSTON 1990, 22.

142. For further discussion on Hecate's role as gatekeeper, see also JOHNSTON 1999, 206-208.

143. von RUDLOFF 1999, 38, fig. 5 .

144. von RUDLOFF 1999, 37.

145. The so-called decree of Molpoi dates to the 5th century BCE and was re-inscribed around 200 BCE (HERDA 2011, 58; GRAVES 2015, 15). For Hecate as protector of the gates and entrances, see also SEIFFERT 2006, 125-133; ZOGRAFOU 2010, 155-159.

146. ZOGRAFOU 2010, 108.

147. See also MORAND 2001, 3, 85-86, 105; ATHANASSAKIS, WOLKOW 2013, 75.

148. See also WERTH 2006, 149, 209-211. A triple marble statue (91 cm high) dating to 161-200 CE was found at Lazio (Italy) that depicts a goddess holding a key, rope, torch, and a knife. The inscription engraved on the statue base reveals that it was dedicated to Diana by Aelius Barbarus, a freed slave of the emperor. A relief from Varna (Bulgaria) dating to the 2nd-3rd centuries CE depicts triple Hecate holding a key, two torches, a knife, and a snake (Archaeological Museum of Varna). A $25.6 \mathrm{~cm}$ high bronze statuette depicts triple Hecate holding a snake, torches, dagger, and a key (Musei Capitolini, Palazzo dei Conservatori). Another bronze statuette of triple Hecate with a key dating to the 2nd - 3rd century CE was found at Classe. The bronze statuette from Classe, a city situated in the province of Ravenna, is preserved at the Museo dell'Accademia Etrusca of Cortona. For details, see GUIDONI $(1982,48 s q)$. A marble triple Hecate holding a key is preserved at the archaeological museum of Istanbul.

149. Not only Hecate and Artemis were depicted with a key in the hand. A triangular bronze tablet from Pergamon dating to the 3rd century CE depicts Phoebe with a key in the hand 
together with Dione and Nyche (MORAND 2001, 182, fn. 147). Phoebe, a Titan goddess associated with the moon, holds a key and a torch. The inscription around Phoebe invokes the goddesses Persephone, Melinoe, and Leucophryne. The key in the hand of Phoebe may be the key of the gate to the underworld.

150. The other prominent sanctuary in the territory of Stratonikeia was the sanctuary of Zeus Panameros at Panamara.

151. LAUMONIER analysed the inscriptions and established the chronology of cultic officials of Lagina (1937, 236-298; Id. 1938, 169-179, 251-284). For the cult and the sanctuary of Hecate at Lagina, see LAUMONIER (1958, 344-425). FILIz DINGIL (now Cluzeau) analysed in her PhD thesis (2006) Principatus devri Karia'sinda leiturgia ve arckhe üstlenen kadınlar (Ankara Üniversitesi) the epigraphic material on female cultic officials in Caria dating to the Imperial period. Her research includes one part of the inscriptions providing evidence for key-bearers of Hecate at Lagina.

152. Iscr. di Cos EV 203 (lines 9-10, 15) from Cos mentions 'Hekateion in Straonikeia'.

153. For Stratonikeia, see also LABUFF 2015,49 sq.

154. AUBRIET 2012, 492-493.

155. SCHOBER 1933, 26.

156. TIRPAN, GIDER, BÜYÜKÖZER 2012, 196sq

157. I.Stratonikeia 705 (lines 9-11), and 735 (line 5).

158. Lagina: I.Stratonikeia 532.2-8 (lines 5-6), 542 (line 3), 543 (line 11), 663 (line 5), 664 (line 6), 666 (line 3), 667 (line 11), 674 (line 20), 676 (line 6), 678 (line 9), 680 (line 4), 683 (line 4), 685 (line 8), 690 (line 10), 693 (lines 3-4, 8), 695 (lines 10-11), 701 (line 9), 702 (lines 2, 4), 704 (line 9), 705 (line 1, 5), 707 (lines 1, 9), 708 (lines 1, 4), 709 (line 1), 710 (line 3), 712 (line 1), 713 (line 1), 735 (line 4), and SEG 52:1089. Panamara: I.Stratonikeia 227 (line 6), 235 (lines 5-6), 237 (lines 6-7), 254 (line 2), 255 (line 7), 256 (line 2), 310 (lines 14-15), 327 (line 4), and 329.5-13 (lines 3-4). Stratonikeia: I.Stratonikeia 1048 (lines 2-3, 6).

159. SEZGIN 2008, 247.

160. I.Stratonikeia 17 (lines 22-24), 538 (lines 3-4), 539 (line 11), 540 (line 2), 711 (lines 2-3), and 1028 (lines 4-5).

161. LAUMONIER 1958, 369.

162. I.Stratonikeia 235 (line 4), 663 (line 6), and 707 (line 3).

163. LAUMONIER 1937, 236-298; Id. 1938, 251-284; Id. 1958, 367. See also QUASS 1993, 315-316.

164. I.Stratonikeia 705, lines 10-11; I.Stratonikeia 735, line 4.

165. I.Stratonikeia 685 , line 8.

166. I.Stratonikeia 704, line 9.

167. I.Stratonikeia 701, line 9; I.Stratonikeia 1048, line 6.

168. WILLIAMSON 2013, 217, fn. 38.

169. AUBRIET 2012, 500.

170. Several inscriptions reveal that the priests and priestesses of Hecate served as gymnasiarchs at the festival of the key: I.Stratonikeia 663 (line 21), 678 (lines 7-8), 685 (lines 7-8), 701 (line 8), and 705 (lines 7-8).

171. I.Stratonikeia 701 (line 9) and 1048 (line 6).

172. I.Stratonikeia 669 (line 6) mentions that the new priest of Hecate opened the temple door of Hecate at the beginning of his priesthood.

173. HATZFELD 1920, 83sq.

174. I.Stratonbikeia 1101 (lines 15-17) records that the priest of Hecate at Lagina selected boys from the neighbourhood for singing of hymns to Hecate. The contests mentioned in Iscr. di Cos EV 203 may have included hymns.

175. See also MOTTE, PIRENNE-DELFORGE 1992, 131.

176. BREMMER 2014, 97-99. 
177. For the telete of Hecate on Aegina, see also SCHUDDEвоOм 2009, 65.

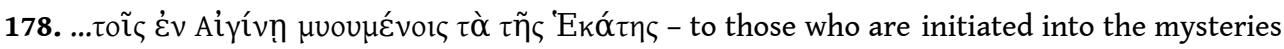
of Hecate (Origen, C. Cels. 6.22).

179. DOWDEN 1980, 416. See also Paus. 1.37.4.

180. DOWDEN 1980, 416.

181. BELAYCHE, Massa 2016, 8.

182. SCHUDDEBOOM gives numerous written sources which illustrate that the term telete was used in connection with mysteries and Orphic rites $(2009,49,97,99,151,221,234)$.

183. BREMMER 2014,107 , fn. 130. For the definition of 'orgia', see MOTTE and PIRENNE-DELFORGE 1992, 120,123

184. See NILSSON 1974, 100; MOTTE and PIRENNE-DELFORGE 1992,128; BREMMER 2014, 107; JACCOTTET 2016, 86. MORAND has analysed the term 'orgiophant' used in epigraphic and literary sources (2001, 243).

185. See also DIEHL, COUSIN 1887, 36sq; ACKERMANN 2013, 22, fn. 52. For further discussion on the mysteries of Hecate, see BREMMER 2013, 97-99.

186. For I.Stratonikeia 310, see also COUSIN, DESCHAMPS 1888, 103-104.

187. See also нотZ 2005, 107.

188. BELAYCHE, MASSA 2016, 8 .

189. BREMMER 2016, 29.

190. BREMMER 2016, 29.

191. ZOGRAFOU 2010, 108.

192. SCULLION 1994, 77.

193. see SCULLION 1994.

194. ZOGRAFOU $2010,108$.

195. ZOGRAFOU 2010,108 sq.

196. KRAUS 1960, 127

197. KRAUS 1960, 127.

198. ZOGRAFOU 2010, 211.

199. A love spell dating to the 4th century CE from Egypt is addressed to Hecate (FARAONE 1997, 196-197). This prayer of a man aims to tie his relationship to a woman. Hecate is invoked with her different names and associated with Selene, Artemis, and Baubo. This prayer emphasizes different aspects of Hecate, and especially her link to the underworld.

200. KÖHLER 1905, 230; DIEHL COUSIN 1887, 36; NILSSON 1906, 401; LAUMONIER 1958, 398, 412, 416sq; KRAUS 1960, 48-50.

201. JOHNSTON 1990, 42.

202. KRAUS $1960,49$.

203. NILSSON $1906,400$.

204. I.Stratonikeia 17 (lines 22-23), 227 (lines 6-9), 235 (lines 5-6), 237 (lines 6-7), 254 (line 2), 326 (line 3), 327 (line 4), 707 (line 1), 708 (lines 1-2), and 1048 (lines 2-3).

205. I.Stratonikeia 664 (lines 6-7), 667 (line 6).

206. I.Stratonikeia 255 (lines 7-8), and 256 (line 2).

207. I.Stratonikeia 17 (lines 23-24), 227 (lines 6-9), 539 (lines 5-7), 663 (lines 17-18), 664 (lines 2021), 666 (lines 3-4), 667 (lines 11-12), 683 (lines 4-6), 702 (line 2), 705 (lines 15-17), and 1028 (lines 4-6).

208. See also LAUMONIER 1938,276 , fn. 4.

209. I.Stratonikeia $227,532.2-8,663,664,666,667,680,683$, and 705 mention the kleidouphoroi who were the daughters of the priests of Hecate at Lagina.

210. For Sempronia Aristonike, see also I.Stratonikeia 290 and 297. 
211. DIEHL COUSIN 1887, 35.

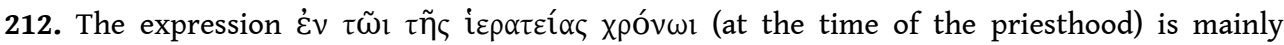
attested for Panamara and for the cult of Zeus. See the inscriptions I.Stratonikeia 161 (line 4), 166 (line 5), 210 (line 5), 227 (lines 9-10), 264 (line 13), 267 (line 5), 287 (line 6), 288 (line 10), 292 (line 5), 293 (lines 26-27), and 662 (line 3).

213. LAUMONIER 1958, 366, fn. 1.

214. LAUMONIER 1938, 265-268.

\section{ABSTRACTS}

Several Linear B tablets from Pylos and 110 inscriptions dating to the Hellenistic, Roman, and Imperial periods provide evidence for cultic officials as key-holders. Numerous grave stelai and vase paintings depict mortal and mythical figures holding the so-called temple key that served as an iconographic insignia of female priests. Studies in the past were primarily focused on the iconographic material. The present paper covers a whole range of epigraphic sources, which give insight into the procedure for appointment to cultic offices of key-holders, their tasks, and social background.

Diverse tavolette in Lineare B da Pilo e 110 iscrizioni di epoca ellenistica e romana testimoniano dell'esistenza di personale di culto addetto alla custodia delle chiavi. Numerose stele funerarie e pitture vascolari rappresentato defunti e figure mitiche che tengono in mano le cosiddette chiavi del tempio insegne sacre quali insegne sacre nelle mani di sacerdotesse. Gli studi precedenti si sono fondamentalmente concentrati sul materiale iconografico. Questo articolo invece intende esaminare un ampio spettro di testimonianze epigrafiche con l'obiettivo chiarire le procedure di nomina del personale sacerdotale addetto alla custodia delle chiavi, le loro funzioni, la loro provenienza sociale.

\section{INDEX}

Keywords: kleidouchos, key-bearer, temple key, Hecate, kleidophoria

Parole chiave: kleidouchos, portachiavi, chiave del tempio, Ecate, kleidophoria

\section{AUTHOR}

\section{AYNUR-MICHÈLE-SARA KARATAS}

University of Bristol

17 Lansdown Road, Saltford

BS31 3BB Bristol (UK)

aramsk(at)my.bristol.ac.uk 